Stjepan Novak*

Izvorni znanstveni rad

UDK 342.565.2: 341.645(4-67EU)

DOI: https://doi.org/10.25234/pv/10408

Rad primljen: 26. veljače 2020.

Rad prihvaćen: 5. lipnja 2020.

\title{
DIJALOZI IZMEĐU USTAVNIH SUDOVA DRŽAVA ČLANICA EUROPSKE UNIJE I SUDA EUROPSKE UNIJE
}

Sažetak: U kontekstu diskursa o ustavnim identitetima, nacionalni ustavni sudovi ulazili su u različite oblike dijaloga sa Sudom EU-a. Nakon duljeg vremena isključivo neizravnih manje ili više uspješnih dijaloga realiziranih kroz vlastitu praksu, nacionalni ustavni sudovi počeli su koristiti mogućnost koju im nudi članak 267. Ugovora o funkcioniranju Europske unije, odnosno institut prethodnog pitanja. Cilj rada je dokazati da su dijalozi koje ustavni sudovi ostvaruju sa Sudom EU-a koristeći ovaj institut najuspješniji oblik njihove komunikacije. U tu svrhu usporedivat ćemo tako vođene dijaloge s neizravnim oblicima komunikacije vodenim izmedu ustavnih sudova i Suda EU-a u ranijim razdobljima. U tom kontekstu autor nakon uvodnih razmatranja, u drugom dijelu, razmatra koncept ustavnog identiteta s gledišta Suda EU-a te s gledišta nacionalnih ustavnih sudova. U trećem dijelu autor analizira različite oblike neizravnih dijaloga između ustavnih sudova i Suda EU-a te se u odnosu na njih donose određeni zaključci o njihovoj uspješnosti. U četvrtom dijelu analiziraju se pojedini postupci koje su pred Sudom EU-a pokrenuli ustavni sudovi te se ukazuje na prednosti i nedostatke ovakvih postupaka. Na kraju, autor zaključuje kako su postupci koje nacionalni ustavni sudovi pokreću na temelju članka 267. Ugovora o funkcioniranju Europske unije najučinkovitiji oblik njihove komunikacije sa Sudom EU-a.

Ključne riječi: nacionalni ustavni sudovi, Sud Europske unije, dijalog, ustavni identitet, prethodno pitanje, članak 267. UFEU-a 


\section{UVOD}

Rad se bavi odnosom koji su svojom praksom razvili Sud Europske unije (dalje: Sud EU-a) i nacionalni ustavni sudovi kroz različite oblike dijaloga. Cilj rada je empirijski dokazati, koristeći se kazuističkom metodom u analizi komparativne ustavnosudske prakse i prakse Suda EU-a, da su postupci pokrenuti na temelju članka 267. Ugovora o funkcioniranju Europske unije (dalje: UFEU), i u slučaju ustavnih sudova najefikasniji i najuspješniji oblik njihova dijaloga sa Sudom EU-a ili barem imaju najviše izgleda da to postanu.

Nakon uvodnih razmatranja u drugom dijelu u osnovnim će se crtama objasniti koncept ustavnog identiteta s gledišta Suda EU-a s jedne strane te s gledišta nacionalnih ustavnih sudova s druge. Identifikacija ustavnog identiteta je važna jer u pozadini svakog dijaloga između ovih sudova stoje upravo temeljne ustavne vrijednosti pojedinih država i ustavne granice integracijskog procesa. ${ }^{1} \mathrm{U}$ trećem dijelu, analizirat će se različiti oblici neizravnih dijaloga koje je Sud EU-a vodio s nacionalnim ustavnim sudovima. Navedeni su dijalozi nekad bili više, a nekad manje uspješni, katkad su se zadržavali na samo jednom susretu Suda EU-a i nekog nacionalnog suda, a katkad su ti dijalozi bili podignuti na međunarodnu razinu te su trajali desetljećima.

Svrha je ovog poglavlja pokazati kako unatoč tome što su navedeni sudbeni akteri vodili određene oblike dijaloga, te su dijaloge, kako će se pokazati, karakterizirali kompleksnost i inertnost, kao nužni rezultati njihove neizravnosti. Ovo vrijedi za sve sudove, pa tako i ustavne koji su dugo odbijali njegovu primjenu.

U četvrtom će se poglavlju istaknuti prednosti i nedostaci ovakvih postupaka te će se prikazati primjeri uspješnih dijaloga između nacionalnih ustavnih sudova i Suda EU-a kroz takve postupke. U završnom dijelu, nakon analize iz prethodnih poglavlja, zaključit će se da je najučinkovitiji način komunikacije između Suda EU-a i nacionalnih ustavnih sudova onaj koji se temelji na članku 267. UFEU-a, odnosno koji se ostvaruje kroz postupke pred Sudom EU-a koji se pokreću kroz institut prethodnog pitanja.

\section{PITANJE USTAVNIH IDENTITETA DRŽAVA ČLANICA}

Članak 4. stavak 2. Ugovora o Europskoj uniji (dalje: UEU)² govori o nacionalnim identitetima država članica, no s obzirom na dio odredbe koji govori o "njihovim temeljnim političkim i ustavnim strukturama”, možemo reći da je zapravo riječ o ustavnim identitetima, ${ }^{3}$ kao osna-

1 von Bogdandy, A.; Schill, S., Overcoming absolute primacy: Respect for national identity under the Lisbon Treaty, Common Market Law Review, vol. 48, br. 5, 2011., str. 1417.-1453., str. 1434.

2 Ugovor o Europskoj uniji dostupno na https://eur-lex.europa.eu/legal-content/HR/TXT/?uri=CELEX\%3 A12016ME\%2FTXT Pristupljeno 9. veljače 2020.

3 Rodin, S., National Identity and Market Freedoms After the Treaty of Lisbon, Croatian Yearbook of European Law and Policy, vol. 7, br.1, 2011., str. 11.-41., str. 14., Horvat Vuković, A., Ustavni sud Republike Hrvatske kao "europski" sud i očuvanje nacionalnih standarda zaštite temeljnih ljudskih prava i sloboda, Zbornik Pravnog fakulteta u Zagrebu, vol. 69, br. 2, 2019., str. 249.-276., str. 256, Cloots, E., National Identity, Constitutional Identity, and Sovereignty in the EU, Netherlands Journal of Legal Philosophy, vol. 45, br. 2, 2016., str. 82.-98., str. 83. 
ženoj verziji nacionalnih identiteta. ${ }^{4}$ Pojam ustavnog identiteta, s teorijskog gledišta, moguće je definirati kao ustavne ideje i načela koje su od temeljne važnosti za određeni ustavni sistem ${ }^{5}$ koji karakterizira promjenjivost, ali i otpornost te koji se različito može manifestirati u različitim situacijama. ${ }^{6}$ To je nerazdvojiva bit ustava. ${ }^{7}$ Ipak, čini se da ovaj pojam Sud EU-a i ustavni sudovi shvaćaju različito. Svakako da su i jedna i druga strana svjesne da u ustavni identitet neće ući svaka ustavna odredba, odnosno svaka vrijednost. ${ }^{8}$ Vidljivo je ovo iz prakse Suda EUa, koja ukazuje na namjeru tog Suda da uzme u obzir elemente nacionalnih identiteta država članica kao odraz njihovih ustavnih poredaka. ${ }^{9}$ Rodin razlikuje "male" i "velike" slučajeve nacionalnog identiteta. I dok su prvi uobičajeni primjer opravdanja javnog poretka, drugi pokazuju svojevrsno ustupanje Suda EU-a pred pojedinim segmentima nacionalnih identiteta. ${ }^{10}$ Ovo je bio slučaj kod supstancijalno vrlo sličnih predmeta Sayn-Wittgenstein, ${ }^{11}$ Runevič-Vardyn ${ }^{12} \mathrm{i}$ Bogendorff von Wolffersdorff. ${ }^{13}$ U predmetu Sayn-Wittgenstein Sud EU-a je osporavani zakon koji austrijskim državljanima zabranjuje upotrebu imena s plemićkim titulama u kontekstu ustavne povijesti Austrije, dijelom nacionalnog identiteta Austrije, uzimajući u obzir načelo proporcionalnosti, kao i njezin status republike. ${ }^{14}$ Vrlo slična situacija bila je i u slučaju Bogendorff von Wolffersdorff, ${ }^{15}$ dok je u predmetu Runevič-Vardyn, Sud EU-a zaštitio nacionalni jezik Litve kao dio njezina nacionalnog identiteta. ${ }^{16} \mathrm{~S}$ druge strane, trivijalnijim odredbama ustavnog prava, kako je to formulirao Besselink, neće se dati prednost pred pravom Europske unije. ${ }^{17}$ Ovo je bio slučaj u predmetu Michaniki ${ }^{18}$ gdje Sud EU-a nije dao prednost odredbama grčkog Ustava, koje su neoborivo zabranjivale vlasnicima, glavnim dioničarima i upraviteljima

Vidjeti i presudu njemačkog Saveznog ustavnog suda 2 BvE 2/08, 2 BvE5/08, 2 BvR 1010/08., 2 BvR 1022/08, 2 BvR 1259/08, 2 BvR 182/09 od 30. lipnja 2009. (u daljnjem tekstu: Lisabonska presuda) dostupna na https://www.bundesverfassungsgericht.de/ SharedDocs/Entscheidungen/EN/2009/06/es20090630-2bve000208 en.html, para 240. Pristupljeno 10. veljače 2020.

4 Besselink, L. F. M., National and constitutional identity before and after Lisbon, Utrecht Law Review, vol. 6, br. 3, 2010., str. 36.-49., str. 37.

5 Bui, S. N., Globalization of Constitutional Identity, Washington International Law Journal, vol. 26, br. 3, 2017., str. 463.-533., str. 469

6 Jacobsohn, G., Constitutional identity, The Review of Politics, vol. 68, br. 3, 2006., str. 361.-397., str. 363.

7 Kostadinov, B., Ustavni identitet, u: Bačić, A. (ur.), Dvadeseta obljetnica Ustava Republike Hrvatske, Hrvatska akademija znanosti i umjetnosti - Znanstveno vijeće za državnu upravu, pravosuđe i vladavinu prava, 2011., str. 305.-337., str. 313.

8 von Bogdandy; Schill, op. cit. u bilj. 1, str. 1430.

9 Cloots, E., National identity in EU Law, Oxford University Press, 2015., str. 7.

10 Rodin, op. cit. u bilj. 3, str. 39.

11 Presuda Suda Europske unije Ilonka Sayn-Wittgenstein protiv Landeshauptmann von Wien, C-208/09, ECLI:EU:C:2010:806 od 22. prosinca 2010., (dalje Sayn-Wittgenstein).

12 Presuda Suda Europske unije Malgožata Runevič-Vardyn $i$ Łukasz Paweł Wardyn protiv Vilniaus miesto savivaldybes administracija $i$ dr., C-391/09, ECLI:EU:C:2011:291 od 12. 5. 2011., (dalje Runevič-Vardyn).

13 Presuda Suda Europske unije Nabiel Peter Bogendorff von Wolffersdorff protiv Standesamt der Stadt Karlsruhe i Zentraler Juristischer Dienst der Stadt Karlsruhe, C-438/14, ECLI:EU:C:2016:401 od 2. lipnja 2014., (dalje Bogendorff von Wolffersdorff).

Sayn-Wittgenstein, para 83. i 91.-93.

15 Bogendorff von Wolffersdorff, para 64. i 73.

16 Runevič-Vardyn, para 85. i 86.

17 Besselink, op. cit. u bilj. 4, str. 48.

18 Presuda Suda Europske unije Michaniki AE protiv Ethniko Symvoulio Radiotileorasis i Ypourgos Epikrateias, C-213/07, ECLI:EU:C:2008:731 od 16. prosinca 2008., (dalje Michaniki). 
medijskih trgovačkih društava sudjelovanje u ugovorima o javnim radovima. ${ }^{19} \mathrm{U}$ predmetu Flemish Government flamanska se vlada pozvala na relevantne ustavne odredbe o podjeli ovlasti između te vlade i savezne vlade kako bi opravdala neispunjenje svojih obveza, u smislu zabrane diskriminacije po osnovi državljanstva, koje proizlaze iz prava tadašnje Zajednice. Sud EU-a ovakvu argumentaciju nije prihvatio. ${ }^{20}$

Zajedno s odredbom članka 4. stavka 3. koja definira načelo lojalne suradnje, odredba članka 4. stavka 2. UEU-a, u sudbenom sustavu Europske unije i njezinih država članica uspostavlja suradnički odnos u kojem će nacionalni sudovi određivati sadržaj nacionalnog, odnosno ustavnog identiteta, a Sud EU-a njegovo značenje u konkretnom sporu, uzimajući u obzir pravo Europske unije, odnosno njegove relevantne odredbe. ${ }^{21}$

Unatoč nekim nedosljednostima po pitanju odluke o tome koji su "veliki”, a koji "mali" slučajevi, ${ }^{22}$ iz prakse Suda EU-a proizlazi da su, s gledišta tog Suda, ustavni identiteti podložni balansiranju, odnosno testu proporcionalnosti, ${ }^{23}$ kao što je to bilo još 2004 . u predmetu Omega. ${ }^{24}$ Kako kažu Drinóczi i Mahoy, praksa Suda EU-a tretira ustavne identitete kao razloge za dopustiva ograničenja prava EU-a na temelju javnog poretka, dok iz odredbe članka 4. stavka 2. proizlazi da je javni poredak dio nacionalnog, ustavnog identiteta. ${ }^{25} \mathrm{~S}$ druge strane, nacionalni ustavni sudovi, koji su najbolje pozicionirani utvrditi ustavni identitet država članica, ${ }^{26}$ drukčije su gledali na ovu situaciju te su ih sami definirali stavljajući se u ulogu njihova zaštitnika.

Tako je njemački Ustavni sud u svojoj odluci o postavljanju prethodnog pitanja Sudu EU$a^{27}$ sukladno članku 267. UFEU-a konstatirao da "njemački ustavni identitet u analizi proporcionalnosti ne može biti izložen balansiranju kao puki legitimni cilj koji se mora praktično usklađivati s pravima koja jamči pravo EU-a." ${ }^{28}$ Taj je ustavni Sud, slikovito "vođa čopora"29 kad je riječ o odnosu nacionalnih ustavnih sudova i Suda EU-a još od svojih znamenitih Solange slučajeva. ${ }^{30}$ U svojoj tzv. Lisabonskoj presudi njemački je Ustavni sud proglasio članak 79. stavak 3.

19 Besselink, op. cit. u bilj. 4, loc. cit.

20 Presuda Suda Europske unije Vlada Communauté française i Gouvernement wallon protiv Gouvernement flamand, C-212/06, ECLI:EU:C:2008:178 od 1. travnja 2008., (dalje Flemish Government), para 57. i 58. Rodin, op. cit. u bilj. 3, str. 21.

21 Rodin, op. cit. u bilj. 3, str. 41. Besselink, op. cit. u bilj. 4, str. 45. von Bogdandy; Schill, op. cit. u bilj. 1, str. 1419.

22 Cloots, op. cit. u bilj. 9, str. 9. Usporediti predmete Sayn-Wittgenstein i Flemish Government.

23 von Bogdandy; Schill, op. cit. u bilj. 1, str. 1420. Rodin, op. cit. u bilj. 3, str. 40.

24 Presuda Suda Europske unije Omega Spielhallen- und Automatenaufstellungs-GmbH protiv Oberbürgermeisterin der Bundesstadt Bonn, C-36/02, ECLI:EU:C:2004:614 od 14. listopada 2004.

25 Drinóczi, T.; Mahoy, A., The Preliminary Ruling Procedure and the Identity Review u: Duić, D.; Petrašević, T. (ur.), Procedural Aspects of EU Law, Jean Monnet International Scientific Conference, 2017., str. 192.-209., str. 198.

26 Vidjeti npr. Rodin, op. cit. u bilj. 3, str 33. Besselink, op. cit. u bilj. 4, str. 45. Preshova, D., Battleground or meeting point? Respect for national identities in the European union - Article 4(2) of the treaty on European union, Croatian Yearbook of European Law and Policy, vol. 8, br.1, 2012., str. 267.-298., str. 296. Mišljenje nezavisnog odvjetnika Madura u predmetu Cristiano Marrosu i Gianluca Sardino protiv Aziedna Ospidaliera Ospedale, C-53/04, ECLI:EU:C:2005:569 od 20.9. rujna 2005., para 40.

27 Odluka njemačkog Saveznog ustavnog suda 2 BvR 2728/13, 2 BvR 2729/13, 2 BvR 2730/13, 2 BvR 2731/13 i 2 BvE 13/13 od 14. siječnja 2014. (u daljnjem tekstu: Odluka OMT).

28 Prijevod iz Horvat Vuković, op. cit. u bilj. 3, str. 259.

29 Claes, M., Luxembourg, Here We Come, German Law Journal, vol. 16, br. 6, 2015., str. 1331.-1342., str. 1341. Vidjeti i Omejec, Veliki njemački ustav i nepromjenjiva ustavna načela u praksi Saveznog ustavnog suda, Zbornik "Pravo i pravda 2015", Pravnog fakulteta Univerziteta u Beogradu, 2016., dostupno na https://www.bib.irb.hr/792156, str. 34. Pristupljeno 10. veljače 2020.

30 Presude njemačkog Saveznog ustavnog suda BVerfGE 37, 271 (2 BvL 52/71) od 29. svibnja 1974. (dalje Solange I.) i BVerfGE 73, 339 (2 BvR 197/83) od 22. listopada 1986. (dalje Solange II.) 
Temeljnog zakona, njegovom nepromjenjivom jezgrom te zaključio kako samo njemu pripada ovlast kontrole je li ta nepovrediva jezgra poštovana. ${ }^{31}$ Ovakva kontrola njemačkog Ustavnog suda dodatak je ultra vires kontroli, ${ }^{32}$ koja omogućava njemačkom Ustavnom sudu ispitivanje poštuje li Europska unija, odnosno pravni akti Europske unije, razgraničenje ovlasti kako je utvrđeno UEU-om i UFEU-om. ${ }^{33}$

Prema uzoru na njemački, češki je Ustavni sud u svojoj presudi Lisbon I. "nedodirljivu srž ustava" povezao s odredbom članka 9. stavka 2. svojeg Ustava koja brani njegove izmjene u odnosu na zahtjeve demokratske države i vladavine prava. ${ }^{34} \mathrm{U}$ presudi Lisbon II. odbio je detaljnije odrediti tu istu srž. ${ }^{35}$

Slično, i poljski Ustavni sud navodi članke Ustava na kojima temelji ustavni identitet, koji smatra ekvivalentom "nacionalnim identitetima" iz članka 4. stavka 2. UEU-a. ${ }^{36}$ Jamac očuvanja ustavnog identiteta, prema zaključku tog Suda, propisan je člankom 90. poljskog Ustava. Tim člankom određene granice prijenosa ovlasti, a u ustavne elemente koji bi svakako trebali biti obuhvaćeni zabranom prijenosa ovlasti spada i nadležnost određivanja nadležnosti koja ostaje u rukama poljskog Ustavnog suda. Uz to, poljski je Ustavni sud nedvosmisleno i jasno ustvrdio u svojoj praksi kako ne priznaje prednost prava Europske unije u odnosu na Ustav i to u njegovoj cjelini. ${ }^{37}$

Mađarski Ustavni sud utvrdio je postojanje ustavnog identiteta kao "ustavnog samo-identiteta” priznatog, ali ne i stvorenog Ustavom, u svojoj odluci od 30. studenog 2016., nabrajajući tek exempli causa određena prava koja su njime obuhvaćena. ${ }^{38}$

Talijanski Ustavni sud formirao je doktrinu "controlimiti” još sedamdesetih godina prošlog stoljeća te u presudi Frontini konstatirao da je svako kršenje temeljnih načela talijanskog Ustava ili neotuđivih ljudskih prava neprihvatljivo te daje talijanskom Ustavnom sudu pravo nadzora nad usklađenošću tadašnjeg Ugovora o Europskoj zajednici s tim načelima. ${ }^{39} \mathrm{U}$ predmetu Granital, pridržao je ovo svoje pravo u slučajevima kad je srž Ustava ugrožena od strane institucija tadašnje Zajednice. ${ }^{40}$ U odluci 1146/1989 izrijekom je utvrdio kako talijanski Ustav

31 Lisabonska presuda, op. cit. u bilj. 3, para 240.

32 Horvat Vuković, op. cit. u bilj. 3, str. 258.

Presuda češkog Ustavnog suda PL US 19/08 od 26. studenoga 2008. dalje (Lisbon I). Vidjeti Preshova., op. cit. u bilj. 26, str. 280.

37 Presude poljskog Ustavnog suda K-45/09 od 16. studenoga 2011., para 2.2. i K-32/09 od 24.10.2010. Vidjeti i von Bogdandy, Schill, op. cit. u bilj. 1, str. 1434.

38 Odluka mađarskog Ustavnog suda 22/2016 (XII 5) od 30. studenoga 2016., Drinóczi, T., Hungarian Constitutional Court: The Limits of EU Law in the Hungarian Legal System, Vienna Journal on International Constitutional Law, vol. 11, br. 1, 2017., str. 139.-151., str. 144.

39 Presuda talijanskog Ustavnog suda N. 183 od 27. prosinca 1973. (dalje: Frontini). Vidjeti Jardim de Santa Cruz Oliveira, M. A., International Trade Agreements Before Domestic Courts, Springer International Publishing, 2015., str. 170.

40 Presuda talijanskog Ustavnog suda N. 170 od 8. lipnja 1984. (dalje Granital) Vidjeti Cartabia, M. The Italian Constitutional Court and the Relationship Between the Italian Legal System and the European Community, Michigan Journal of International Law, vol. 12, br. 1, 1990., str. 173.-203., str. 181. 
sadrži neka vrhovna načela čiji se temeljni sadržaj ne smije srozati niti izmijeniti ni revizijama Ustava ni ustavnim zakonima. ${ }^{41}$

U kontekstu određivanja granica integracijskog procesa i španjolski je Ustavni sud konstatirao da su te materijalne granice, koje nisu izrijekom navedene u integracijskoj ustavnoj klauzuli članka 93., ali koje proizlaze iz samog Ustava, "suverenitet države, temeljne ustavne strukture i sustav fundamentalnih načela i vrijednosti uspostavljenih Ustavom u kojem fundamentalna prava stječu vlastitu supstancijalnu prirodu" ${ }^{42}$

U svojoj Odluci 2006-540 DC ${ }^{43}$ francusko je Ustavno vijeće utvrdilo da "implementacija direktiva Europske unije ne može ići protiv pravila ili načela koja su sastavni dio ustavnog identiteta Francuske, osim ako je ustavotvorac na to pristao." ${ }^{44}$ Kostadinov navodi da je u konkretnom slučaju riječ bila o posebnostima francuskog Ustava za koje nema ekvivalenta u pravu Europske unije, konkretno načelu laïcité, obliku sekularizma specifičnom za Francusku. U nastavku zaključuje: "Ustavno vijeće Francuske je imalo 2006. godine, prigodom oblikovanja ustavnog identiteta, jasan politički cilj: zaštitu jezgre nacionalne suverenosti. Pretpostavka je bila da svaki ustav koji je podređen nekom eksternom pravnom pravilu ne može biti podređen u cijelosti i mora očuvati neka esencijalna načela." ${ }^{45}$

I Ustavni sud Republike Hrvatske (u daljnjem tekstu USRH) u svojoj je praksi definirao ustavni identitet Republike Hrvatske. ${ }^{46}$ U Odluci od 29. srpnja 2011. naveo je kako je ustavni identitet određen u stavku 2. Izvorišnih osnova, koji se odnosi na ravnopravnost nacionalnih manjina, ${ }^{47}$ pa Horvat Vuković navodi da se ova odluka može smatrati "prvom naznakom promišljanja hrvatske teorije ustavnog identiteta". ${ }^{48}$

U Priopćenju od 14. studenoga 2013., USRH je u ustavni identitet smjestio članak 1. Ustava koji se odnosi na jedinstvenost i nedjeljivost Republike Hrvatske kao demokratske i socijalne države te članak 3. koji određuje najviše vrednote ustavnog poretka Republike Hrvatske, ${ }^{49}$ što je ponovio i u Upozorenju od 28. listopada 2013..$^{50}$ i u Odluci od 8. travnja 2015. ${ }^{51}$ U Odluci od 12. kolovoza 2014. kao ustavni identitet odredio je načelo poštovanja jezika i pisma nacional-

41 Odluka talijanskog Ustavnog suda N. 1146 od 15. do 29. prosinca 1988., para 2.1.

42 Presuda španjolskog Ustavnog suda 1/2004 od 13. prosinca 2004. Vidjeti i Blagojević, Procedures Regarding National Identity Clause in the National Constitutional Court's and the CJEU's Case-law u: Duić, D.; Petrašević, T. (ur.), Procedural Aspects of EU Law, Jean Monnet International Scientific Conference, 2017., str. 210.-237., str. 221.

43 Odluka francuskog Ustavnog vijeća 2006-540 DC od 27. srpnja 2006.

44 Kostadinov, op. cit. u bilj. 7, str. 315.

45 Kostadinov, op. cit. u bilj. 7, str. 316.

46 Horvat Vuković, op. cit. u bilj. 3, str. 261. Blagojević, op. cit. u bilj. 42, str. 224.-229.

47 Odluka USRH U-I-3597/2010, U-I-3847/2010, U-I-692/2011, U-I-898/2011 i U-I-994/2011 od 29. srpnja 2011. , para 30.1. dostupna na https://sljeme.usud.hr/Usud/Praksaw.nsf/ C12570D30061CE54C12578DC00 393E6E/\$ FILE/U-I-3597-2010. pdf. Pristupljeno 10. veljače 2020.

48 Horvat Vuković, A., "U ime ustava" - materijalne granice promjene ustava, Zbornik Pravnog fakulteta u Zagrebu, vol. 65, br. 3-4, 2015., str. 481.-503., str. 489.

49 Priopćenje USRH Broj: SuS-1/2013 od 14. studenoga 2013., para 5.3. https://sljeme.usud.hr/Usud/Praksaw. nsf/3EB0F70A0C597481C1257C9F002F28C7/\$FILE/SuS-1-2013\%20-\%20PRIOPĆENJE.pdf. Pristupljeno 10. veljače 2020.

50 Upozorenje USRH U-VIIR-5292/2013 od 28. listopada 2013., para 3. https://sljeme.usud.hr/Usud/Praksaw.nsf/ C12570D3006 1CE54C1257C12004D2CCE/\$FILE/U-VIIR-5292-2013.pdf. Pristupljeno 10. veljače 2020.

51 Odluka USRH U-VIIR-1159/2015 od 8. travnja 2015., para 33.4. https://sljeme.usud.hr/ Usud/Praksaw.nsf/8AE551 C5A1A1538BC1257E26002BE3F2/\$FILE/U-VIIR-1159-2015.pdf. Pristupljeno 10. veljače 2020. 
nih manjina iz članka 12. stavka 2. Ustava $\mathrm{RH},{ }^{52}$ a u Odluci od 21. travnja 2015., članak 49. stavak 1. Ustava koji se odnosi na poduzetničku i tržišnu slobodu kao temelje gospodarskog ustroja Republike Hrvatske. ${ }^{53}$ Koncept ustavnog identiteta USRH je primijenio i u Odluci od 10. listopada $2017 .^{54}$

Cilj ovog prikaza bio je ukazati na činjenicu da za države članice Europske unije, odnosno njihove ustavne sudove, ustavni identitet nikako nije, kako je ustvrdio njemački Ustavni sud, "puki legitimni cilj", odnosno tek jedna od nacionalnih specifičnosti na koju se, prema potrebi, država može pozivati s ciljem derogacije obveza koje ima na temelju članstva u Europskoj uniji. Riječ je o srži ustava, o njegovoj nepovredivoj jezgri, o temeljnim vrijednostima koje moraju biti poštovane i koje će zadržati prednost u odnosu na pravo Europske unije.

Sukob između ustavnih sudova i Suda EU-a svodi se na položaj temeljne norme unutar specifičnog pravnog sustava kao što je Europske unija. Pitanje nacionalnog identiteta usko je povezano s pitanjem ustavnih granica, odnosno pitanjem tko je nadležan odlučiti o nadležnosti, odnosno ostaje li određena mjera europskih tijela unutar ovlasti koje su im dodijeljene. ${ }^{55}$ Ova pitanja ključna su za odnos Suda EU-a i ustavnih sudova država članica, ${ }^{56}$ a na njihovu povezanost ukazuje i gore navedena praksa, posebice Lisabonska presuda njemačkog Ustavnog suda.

U ovim sukobima, riječ je o svojevrsnoj pat-poziciji, srazu pojedinačnih odluka nacionalnih ustavnih sudova s jedne, i nadležnosti Suda EU-a da interpretira članak 4. stavak 2. na temelju članka 19. UEU-a, s druge strane. ${ }^{57}$ Iz tih sukoba, koji su postojali od samog početka integracijskog procesa, kao nužna javlja se potreba za njegovim rješavanjem, za dijalogom između suprotstavljenih strana. ${ }^{58}$ Svakako najbolji način za ostvarivanje konstruktivnog dijaloga podrazumijeva institut prethodnog pitanja. Ustavni sudovi, međutim, nisu uvijek bili skloni korištenju današnjeg članka 267. te je trebalo proći dosta vremena da prihvate ovakav način komunikacije.

U sljedećem poglavlju, usporednom praksom, ${ }^{59}$ prikazat će se načini na koji su ustavni sudovi država članica Europske unije neizravno komunicirali sa Sudom EU-a i ispitivati učinkovitost takve prakse.

52 Odluka USRH U-VIIR-4640/2014 od 12. kolovoza 2014., para 13.1. https://sljeme.usud.hr/Usud/Praksaw.nsf /00DF3D904C3C A481C1257D320052C3F2/\$FILE/U-VIIR-4640-2014.pdf. Pristupljeno 10. veljače 2020.

Odluka USRH U-VIIR-1158/2015 od 21. travnja 2015, para 43.1. https://sljeme.usud.hr/Usud/Praksaw.nsf/ C12570D30061CE 54C1257E2E0046F4DD/\$FILE/U-VIIR-1158-2015.pdf. Pristupljeno 10. veljače 2020. 61CE54C12581B5003D8E75/\$FILE/U-II-6111-2013.pdf. Pristupljeno 10. veljače 2020.

55 Ćapeta, Nacionalni Ustav i nadređenost prava EU u eri pravnog pluralizma, Zbornik Pravnog fakulteta u Zagrebu, vol. 59, br. 1, 2009., str. 63.-96., str. 76. i 77.

56 Preshova, op. cit. u bilj. 26, str. 267.

57 von Bogdandy; Schill, op. cit. u bilj. 1, str. 1447.

58 Vidjeti Ćapeta, op. cit. u bilj. 55, str. 93.

59 Rodin, Odnos Ustavnog suda RH i Suda pravde Europskih zajednica u Luxembourgu nakon ulaska Republike Hrvatske u punopravno članstvo u Europskoj uniji u: Barbić, J. (ur.), Hrvatsko ustavno sudovanje, Hrvatska akademija znanosti i umjetnosti, 2009., str. 247.-277., str. 1.-26., str. 5. Claes, op. cit. u bilj. 29, str. 1336. 


\section{NEIZRAVNI DIJALOZI USTAVNIH SUDOVA I SUDA EU-A KROZ USPOREDNU PRAKSU}

U presudi Costa v. E. N. E. L. Sud EU-a je ustvrdio "da nacionalne odredbe, bez obzira na to kako su formulirane, ne mogu imati prvenstvo nad pravom koje proizlazi iz Ugovora, koji je autonoman izvor prava, zbog njegove posebne i originalne prirode, a da pri tome to pravo ne izgubi svoj karakter prava Zajednice i da se pri tome ne dovede u pitanje sam pravni temelj Zajednice." ${ }^{60}$ Ova je presuda u temelju europskog nadnacionalnog konstitucionalizma ${ }^{61}$ te je, kako navodi Kostadinov, primjer sudbene revolucije ili sudbenog državnog udara, s obzirom na to da države članice nisu propisale nadređenost prava Europske unije, odnosno tadašnje Zajednice niti Osnivačkih ugovora. ${ }^{62}$ Najjednostavnije, ta je presuda uspostavila nadređenost europskog prava cjelokupnom nacionalnom pravu. Na ovakav se potez Sud EU-a nije odlučio bez povoda. Bio je to odgovor na praksu talijanskog Ustavnog suda koji je, tijekom prve polovice šezdesetih godina prošlog stoljeća, na odredbe Zajednice gledao kao na norme istog izvora kao i odredbe nacionalnog zakonodavstva pa je u slučaju njihova eventualna sukoba potrebno primijeniti načelo lex posterior derogat legi priori. Dakle, svaki naknadno doneseni nacionalni akt mogao je derogirati pravo Zajednice što nije moglo biti prihvatljivo s gledišta tadašnje Zajednice. ${ }^{63}$ Presuda Suda EU-a uslijedila je nekoliko mjeseci poslije.

Daljnja praksa talijanskog Ustavnog suda i dalje je bila problematična za Sud EU-a. Kako navodi Cartabia, taj je Sud uspostavio pravilo prema kojem se, u slučaju kad je nacionalna norma usvojena nakon neke norme Zajednice, a suprotna je toj istoj normi, predmet treba uputiti talijanskom Ustavnom sudu. ${ }^{64}$ Odgovor Suda EU-a došao je u ožujku 1978. U presudi Simmenthal ustanovljeno je pravilo prema kojem nacionalni sudac, u konkretnom postupku, u okviru svojih nadležnosti, treba osigurati puni učinak odredbama prava Zajednice, odbijajući, prema potrebi, na vlastitu inicijativu, primjenu svake suprotne odredbe nacionalnog prava pa čak i ako je ona naknadno usvojena. U ovakvom postupku, prema istom pravilu, nacionalni sudac ne mora tražiti niti čekati prethodno stavljanje izvan snage te nacionalne odredbe u zakonodavnom postupku ili na bilo koji drugi ustavnom predviđen način. ${ }^{65} \mathrm{Na}$ taj način snaga redovnih nacionalnih sudova raste, a ustavnih sudova pada. ${ }^{66}$

Dijalog izražen u Simmenthalu nastavio se i više od trideset godina poslije, poprimivši međunarodnu dimenziju. U pravnom sustavu Francuske, nakon usvajanja Lisabonskog ugovora,

60 Presuda Suda Europske unije Flaminio Costa protiv E.N.E.L., C-6/64, ECLI:EU:C:1964:66 od 15. srpnja 1964, prijevod dostupan na https://curia.europa.eu/jcms/upload/docs/application/pdf/2014-02/tra-doc-hr-arret-c-0006-1964-201304451-05-00.pdf. Pristupljeno 10. veljače 2020.

61 Rodin, Pravo Europske unije i pravni poredak Republike Hrvatske nakon 20 godina hrvatskog ustava, Zbornik HAZU Zagreb, Hrvatska, 2010., str. 1.-31., str. 6.

62 Kostadinov, op. cit. u bilj. 7, str. 313.

63 Presuda talijanskog Ustavnog suda, N. 14. od 7. ožujka 1964., Cartabia, op. cit. u bilj. 40, str. 177.

64 Cartabia, op. cit. u bilj. 40, loc. cit.

65 Presuda Suda Europske unije Amministrazione delle Finanze dello Stato protiv Simmenthal SpA C-106/77, ECLI:EU:C:1978:49 od 9.3.1978., para 24., prijevod dostupan na https://curia.europa.eu/jcms/upload/docs/ application/pdf/2014-02/tra-doc-hr-arret -c-0106-1977-201304454-05-01.pdf. Pristupljeno 10. veljače 2020. 
provedena je ustavna reforma. ${ }^{67} \mathrm{U}$ tako reformiranom sustavu, u svakom predmetu u kojem dolazi do potencijalnog neslaganja između francuskog i međunarodnog prava koje obvezuje Francusku, redovni nacionalni sud dužan je pokrenuti postupak pred Kasacijskim sudom, odnosno Državnim vijećem, nakon čega ova tijela mogu pokrenuti postupak pred Ustavnim vijećem, preko instituta prethodnog prioritetnog pitanja. Na takav način ne samo da se negativno utječe na ovlast redovnog suda da postavlja prethodna pitanja Sudu EU-a, već se neutralizira ovlast koju redovni sud ima na temelju Simmenthal presude. ${ }^{68}$ Odgovor Suda EU-a stigao je u predmetu Melki i Abdeli, u kojem je Sud EU-a utvrdio da redovni sudovi moraju moći:

- u kojoj god fazi postupka to smatrali primjerenim, čak i na kraju incidentalnog postupka za ocjenu ustavnosti, uputiti Sudu bilo koje prethodno pitanje koje smatraju potrebnim

- $\quad$ usvojiti sve mjere potrebne kako bi se osigurala privremena sudska zaštita prava koja proizlaze iz pravnog poretka Unije i

- $\quad$ izuzeti od primjene, na kraju takvog incidentalnog postupka, nacionalnu zakonsku odredbu ako je smatraju protivnom pravu Unije. ${ }^{69}$

Austrijski Ustavni sud donio je, u ožujku 2012., odluku iz koje je proizlazilo da austrijski sudovi, u okviru svoje nadležnosti, nisu ovlašteni izuzeti od primjene zakon protivan Povelji Europske unije o temeljnim pravima, već su dužni, "bez učinka na mogućnost upućivanja zahtjeva za prethodnu odluku Sudu"70 postaviti zahtjev za opće ukidanje tog zakona austrijskom Ustavnom sudu. Iz iste je odluke proizlazilo i da nema potrebe za upućivanjem prethodnog pitanja Sudu EU-a u slučaju kada "pravo zajamčeno austrijskim Ustavom ima isto područje primjene kao pravo zajamčeno Poveljom." ${ }^{71}$ Sud EU-a dao je identičan odgovor kao i u predmetu Melki i Abdeli. ${ }^{72}$

Niti u jednom od navedenih predmeta Sud EU-a nije odlučivao u povodu zahtjeva ustavnog suda za prethodnom odlukom.

Prikazane slučajeve gotovo da bismo prije mogli nazvati lekcijom nego dijalogom u užem smislu riječi. Čini nam se da je Sud EU-a zapravo učio ustavne sudove pravilima igre u okviru Europske unije reagirajući na njihovu praksu svojom. Dvije izrazito važne presude Suda EU-a, Costa v. E. N. E. L. i Simmenthal, donesene su kao odgovor na praksu talijanskog Ustavnog suda koja nije bila usklađena s pravom tadašnje Zajednice te je na svaku od njih talijanski Ustavni sud reagirao mijenjajući, u većoj ili manjoj mjeri, svoju praksu. I u francuskom i austrijskom slučaju Sud EU-a održao je zapravo identičnu lekciju ovim ustavnim sudovima, iako su, u tim slučajevima, zahtjeve za prethodnu odluku podnijeli redovni, a ne ustavni nacionalni sudovi. Je li lekcija bila usvojena, pokazat će buduća praksa konkretnih ustavnih sudova. Međutim, nedostatak ovakve komunikacije nije samo spomenuta neizravnost zbog koje ustavni sudovi nisu u prilici argumentirano iznijeti eventualne specifičnosti vezane za nacionalni identitet, već i njihova dugotrajnost.

\footnotetext{
67 Rodin, op. cit. u bilj. 3, str 35.

68 Rodin, op. cit. u bilj. 61, str. 25.

69 Presuda Suda Europske unije Aziz Melki i Sélim Abdeli, C-188/10 i C-189/10, ECLI:EU:C:2010:363 od 22. lipnja 2010., para 57.

70 Presuda Suda Europske unije A protiv B, C-112/13., ECLI:EU:C:2014:2195 od 11. rujna 2014., para 25.

71 Ibid.

72 Presuda A protiv B, op. cit. u bilj. 70, para 46.
} 
Posebno važan, ali i dugotrajan dijalog vodio se oko zaštite temeljnih ljudskih prava koje osiguravaju ustavni akti. Sud EU-a je još sedamdesetih godina prošlog stoljeća u presudi Internationale Handelsgesellschaft potpuno nedvosmisleno ustvrdio kako navodi pojedine države članice da se određena mjera Zajednice protivi temeljnim pravima utvrđenim ustavom te države ili temeljnim načelima njezine ustavne strukture, ne mogu utjecati niti na valjanost te mjere Zajednice niti na njezin učinak u okviru pravnog poretka države članice. ${ }^{73}$

Talijanski Ustavni sud na to je odgovorio u presudi Frontini. Izričaj ove presude pokazuje da talijanski sud ustraje pri gledištu da, kako kaže Rodin, "pravo Zajednice ne može ograničiti nacionalni sustav zaštite temeljnih prava, odnosno nacionalnu ustavnu ravnotežu, te da o tome u konačnoj instanci imaju odlučivati nacionalni ustavni sudovi, a ne Europski sud." ${ }^{44} \mathrm{U}$ razdoblju kada zaštita ljudskih prava još nije u središtu interesa Suda EU-a ${ }^{75}$ ovo zapravo vrijedi i za druge ustavne sudove država članica jer oni ne mogu dopustiti da načelo nadređenosti utječe na kvalitetu zaštite temeljnih ljudskih prava koja štite ustavi.

Sud EU-a je, na ovakvu ustavnosudsku praksu država članica odgovorio u predmetu Nold iz svibnja 1974. Kao što je poznato, taj je Sud konstatirao da temeljna prava čine sastavni dio općih načela prava čije poštovanje taj Sud osigurava te da je u zaštiti tih prava obvezan crpiti inspiraciju iz ustavnih tradicija zajedničkih svim državama članicama te ne može poduprijeti mjere koje nisu u skladu s temeljnim pravima utvrđenim i osiguranim ustavima država članica. Također, smjernice koje treba slijediti u okviru prava tadašnje Zajednice mogu pružiti međunarodni sporazumi za zaštitu ljudskih prava, na kojima su surađivale ili čije su stranke države članice. ${ }^{76} \mathrm{Iz}$ ovog je primjera očito kako je praksa ustavnih sudova neizravno utjecala na podizanje razine zaštite temeljnih prava u tadašnjoj Zajednici ili barem, u tom trenutku, na podizanje razine svijesti o potrebi njihove zaštite.

Po donošenju presude Nold, glavnu ulogu u ovom međunarodnom ustavnosudskom dijalogu, preuzeo je njemački Ustavni sud u svojoj znamenitoj Solange I. presudi, postavljajući na prvo mjesto, u svakoj hijerarhiji pravnih pravila, temeljna prava iz svog Temeljnog zakona. U predmetu Solange II., njemački je Ustavni sud ublažio svoj stav, a ovaj se dijalog nastavio i dalje. Diskurs koji je postojao još od presude FRAGD, ${ }^{77}$ ostao je prisutan i dalje. Ta je presuda, kako navodi Besselink, postavila među ustavnim sudovima trend sužavanja prednosti ustava na temeljne ustavne vrijednosti, odnosno načela, ${ }^{78}$ poslije nastavljen u Solange presudama njemačkog Ustavnog suda i već spomenutoj presudi francuskog Ustavnog vijeća 2006-540 DC. ${ }^{79}$ Naime, u presudi FRAGD kaže se da pravo Zajednice neće moći stupiti na snagu u Italiji ako

73 Presuda Suda Europske unije Internationale Handelsgesellschaft mbH protiv Einfuhr- und Vorratsstelle für Getreide und Futtermittel, C-11/70, ECLI:EU:C:1970:114 od 17. prosinca 1970.

Rodin, op. cit. u bilj. 59, str. 6. ECLI:EU:C:1974:51 od 14. svibnja 1974., para 13. 
krši temeljna načela zaštite ljudskih prava talijanskog Ustava pa čak i ako je Sud EU-a utvrdio valjanost konkretnog prava. ${ }^{80}$

U ovom tonu zapravo je bila i Lisabonska presuda njemačkog Ustavnog suda. Važnost ove presude je dvostruka. S jedne strane, presuda je proglasila otvorenost i prijateljski odnos prema pravu Europske uniju, a s druge je uvela "kontrolu identiteta", kao dodatni nadzorni mehanizam nad pravom Europske unije i poštovanje granica ovlasti koje su tim pravom dodijeljene tijelima Europske unije. Raniji nadzorni mehanizam oslanjao se na ultra vires kontrolu i "kontrolu poštovanja nepovredive srži temeljnih ustavnih prava". ${ }^{81}$ Također, u ovoj je presudi njemački Ustavni sud utvrdio postojanje mogućnosti da, iznimno i pod posebnim i specifičnim uvjetima, pravo Europske unije proglasi neprimjenjivim u Njemačkoj, kao i u izričaju češkog Ustavnog suda u predmetu Lisbon . $^{82}$ Talijanski Ustavni sud, uspostavljajući controlimiti doktrinu u spomenutom predmetu Granital, ustvrdio je malo vjerojatnom mogućnost da će doći do ispitivanja valjanosti prava tadašnje Zajednice $u$ odnosu na temeljna načela talijanskog Ustava. U FRAGDU je, pak, zaključio da je, ono što je malo vjerojatno, još moguće. ${ }^{83}$ Konačno, presuda Bananamarket, svojevrsna potvrda Solange II. ustanovila je pravilo da sve ustavne žalbe te podnesci sudova moraju detaljno dokazivati da pravo Zajednice, uključujući i presude Suda EU-a, nije uspjelo na odgovarajući način zajamčiti esencijalnu i neotuđivu zaštitu temeljnih prava zajamčenih njemačkim Ustavom. U suprotnom smatrat će se nedopustivima. ${ }^{84}$

"Kontrolu identiteta" uvedenu Lisabonskom presudom njemački je Ustavni sud, prvi put, upotrijebio u odluci Solange III. ${ }^{85}$ Ta je odluka dio još jednog dijaloga Suda EU-a i nacionalnih ustavnih sudova i to dijaloga koji se može izdvojiti kao primjer njihove konstruktivne i kvalitetne komunikacije. Možemo reći da je dijalog započeo kada je španjolski Ustavni sud, u srpnju 2011., prvi put uputio zahtjev za prethodnu odluku Sudu EU-a. Pitanje je bilo u vezi s Okvirnom odlukom Vijeća od 13. lipnja 2002. o Europskom uhidbenom nalogu i postupcima predaje između država članica (2002/584/PUP, u daljnjem tekstu: Okvirna odluka). Naime, španjolsko je ustavno pravo, odnosno ustavnosudska praksa jamčila višu razinu zaštite prava osoba osuđenih u odsutnosti nego talijansko pravo, a navedena Okvirna odluka nije predviđala ovu okolnost kao razlog odbijanja izvršenja naloga. ${ }^{86}$ Slijedom toga, prije izručenja gospodina Mellonija Italiji, španjolski se Ustavni sud obratio Sudu EU-a. Sud EU-a donio je, 23. veljače 2013. još jednu kontroverznu odluku. Štiteći načelo nadređenosti prava EU-a i njegovu

80 Jardim, de Santa Cruz Oliveira, op. cit. u bilj. 39, loc. cit.

81 Lisabonska presuda, op. cit. u bilj. 3, para 219. i 240. Horvat Vuković, op. cit. u bilj. 3., str. 258.

82 Lisabonska presuda, op. cit. u bilj. 3, para 340, Lisbon I., op. cit. u bilj. 34., para 102.-108. Vidjeti i Preshova, op. cit. u bilj. 26, str. 293., bilj. 136.

83 Cartabia, op. cit. u bilj. 40, str. 183.

84 Odluka njemačkog Saveznog ustavnog suda 2 BvL 1/97 od 7. lipnja 2000., para 62.

85 Odluka njemačkog Saveznog ustavnog suda 2 BvR 2735/14 od 15. veljače 2015. (dalje Solange III.). Drinóczi; Mahoy, op. cit. u bilj. 25, str. 200.

86 Vidjeti Franssen, V., Melloni as a Wake-up Call - Setting Limits to Higher National Standards of Fundamental Rights' Protection, European Law Blog, News and Comments on EU Law, 10. ožujka 2014., dostupno na https://europeanlawblog.eu/2014/03/10/ melloni-as-a-wake-up-call-setting-limits-to-higher-national-standards-of-fundamental-rights-protection/. Pristupljeno 9. veljače 2020. Kustra, A., The First Preliminary Questions to the Court of Justice of the European Union Referred by Italian Corte Costituzionale, SpanishTribunal Constitucional and French Conseil Constitutionnel, Comparative Law Review, vol. 16, 2013., str. 159.-182., str. 169. 
uniformnu primjenu, zaključio je da, unatoč članku 53. Povelje EU-a o temeljnim pravima, ${ }^{87}$ odstupanje od odredbi Okvirne odluke nije dopušteno čak i kad je zaštita temeljnih prava u pravnom poretku države članice na višoj razini nego u pravnom poretku Europske unije. ${ }^{88}$

U veljači 2015., njemački se Ustavni sud našao u sličnoj situaciji kao i španjolski u predmetu Melloni. Tom je prilikom, ne odustajući od načela otvorenosti prema pravu Europske unije, ${ }^{89}$ njemački Sud proveo svoju "kontrolu identiteta" koju je relevantno pravo Europske unije, počevši s Okvirnom odlukom, uspješno prošlo. ${ }^{90}$ Ipak, istaknuo je kako je prednost primjene prava Europske unije ograničena ustavnim načelima koja su izvan integracijskog procesa te koja su ukorijenjena u ljudskom dostojanstvu. Njemački Ustavni sud će ih nastaviti provjeravati u svakom pojedinačnom slučaju koji je dovoljno detaljno obrazložen, uz uvjet da se Sud EU-a imao prilike očitovati o slučaju kroz institut prethodnog pitanja. ${ }^{91}$

Ovakvo je stajalište njemačkog Ustavnog suda rezultiralo ublažavanjem stajališta Suda EUa. Sud u Bremenu postavio je Sudu EU-a prethodno pitanje u vezi s pravnom regulativom o Europskom uhidbenom nalogu, konkretno, sprječavaju li izvršenje europskog uhidbenog naloga čvrsti dokazi ozbiljnih elemenata koji svjedoče o neusklađenosti uvjeta oduzimanja slobode u državi članici izdavateljici s temeljnim pravima. ${ }^{92}$ Sud EU-a je u predmetu Aranyosi i Căldăraru odgovorio da u takvim slučajevima nadležno tijelo države članice izvršenja treba "na konkretan i precizan način ispitati postoje li u slučaju predaje navedenoj državi članici ozbiljni i utvrđeni razlozi za vjerovanje da će osoba na koju se odnosi europski uhidbeni nalog u svrhe izvršenja kaznenog progona ili izvršenja kazne oduzimanja slobode zbog uvjeta oduzimanja njezine slobode biti izložena stvarnoj opasnosti od podvrgavanja neljudskom i ponižavajućem postupanju u smislu članka 4. Povelje Europske unije o temeljnim pravima." ${ }^{33} \mathrm{U}$ tu svrhu ono od nadležnih tijela države koja je nalog izdala treba tražiti dodatne podatke te dok ih ne dobije mora odgoditi svoju odluku o predaji. "Ako postojanje te opasnosti ne može biti otklonjeno u razumnom roku, to tijelo mora odlučiti treba li obustaviti postupak predaje." ${ }^{94}$ Sud EU-a je, zapravo, potvrdio stav njemačkog Ustavnog suda u presudi Solange III. prema kojem je u individualnim i specifičnim slučajevima na osnovi zaštite temeljnih prava, moguće odbiti izvršenje Europskog uhidbenog naloga.${ }^{95}$ Nastavak ovog prilično uspješnog dijaloga, ${ }^{96}$ uslijedio je

87 Povelja Europske unije o temeljnim pravima dostupno na https://eur-lex.europa.eu/legal-content/HR/TXT/PDF/ ?uri=CELEX:12016P/TXT\&from=FR. Pristupljeno 9. veljače 2020.

Presuda Suda Europske unije Ministerio FiscalAnte el Tribunal Constitucional protiv Stefano Melloni,, C-399/11, ECLI:EU:C:2013:107, od 26.2.2013., para 63. Nakanishi, Y., Completion of EU Measures Through Court Decisions: The Example of the European Arrest Warrant, Hitotsubashi journal of law and politics, vol. 45, 2017., str. 13-21., str. 18. Horvat Vuković, op. cit. u bilj. 3, str. 254.

Solange III. op. cit. u bilj. 85, para 45. i 49.

Solange III. para 85. Vidjeti i Nowag, J., A new Solange judgment from Germany - or nothing to worry about? Völkerrechtsblog, 22. ožujka 2016. DOI: 10.17176/20171201.110929 dostupno na https://voelkerrechtsblog. org/a-new-solange-judgment-fromgermany-or-nothing-to-worry-about/. Pristupljeno 9. veljače 2020.

91 Solange III. op. cit. u bilj. 85, para 36., 46. i 50. Horvat Vuković op. cit. u bilj. 3, str. 260.

Presuda Suda Europske unije, Pál Aranyosi i Robert Căldăraru, C-404/15 i 659/15 PPU, ECLI:EU:C:2016:198 od 5. travnja 2016. (dalje: Aranyosi i Căldăraru) para 74. Nakanishi, op. cit. u bilj. 88, str. 18. 
u odluci njemačkog Ustavnog suda 2 BvR 890/16 u kojem je taj Sud vrlo jasno demonstrirao otvorenost prema pravu Europske unije koje uređuje Europski uhidbeni nalog. ${ }^{97}$

Opisani slučajevi još su jedan primjer kako i neizravni dijalozi između jednog nacionalnog ustavnog suda i Suda EU-a mogu biti vrlo uspješni. Dakle, iako među njima nije bilo izravne komunikacije, i njemački Ustavni sud i Sud EU-a, međusobni su utjecaj promijenili svoju praksu. Ovo je bila posljedice međusobnog uvažavanja i otvorenosti njemačkog suda prema pravu Europske unije.

Otvorenost prema pravu Europske unije, barem službeno, isticao je i Ustavni sud Češke. ${ }^{98}$ Diskutabilnost svog stava o otvorenom odnosu češki Ustavni sud nije pokazao samo u svojim Lisabonskim presudama, već i u jednom drugom slučaju koji predstavlja primjer vjerojatno najneuspješnijeg neizravnog dijaloga između jednog nacionalnog ustavnog suda i Suda EUa. Riječ je bila o predmetu Holubec. Problematiku iz domene mirovinskog osiguranja nastalu raspadom bivše Čehoslovačke, oko koje se vodio višegodišnji sukob između češkog Ustavnog i Visokog upravnog suda, svojom je presudom odlučio riješiti Ustavni sud. Taj ju je Sud riješio na način da je na isplatu izvjesne naknade po osnovi mirovinskog osiguranja ovlašćivao isključivo češke državljane koji žive na teritoriju Češke. Sumnjajući da je način koji je izabrao Ustavni sud sukladan pravu Europske unije, Visoki upravni sud postavio je pitanje Sudu EUa. ${ }^{99} \mathrm{U}$ svojoj je presudi Sud EU-a uistinu potvrdio da je presuda češkog Ustavnog suda suprotna načelu zabrane diskriminacije. ${ }^{100}$ Reakcija češkog Ustavnog suda, u prvom sličnom slučaju koji se pred njim pojavio, bila je vrlo burna. Riječ je bila o njegovoj odluci u predmetu Holubec. Prvi je put ustavni sud jedne države članice Europske unije proglasio akt tijela Europske unije, i to presudu Suda EU-a, kao odluku ultra vires, koristeći pritom, prilično oštru, ali ne i posebno jasnu argumentaciju. Ta se argumentacija temeljila na navodnom nerazumijevanju Suda EU-a pravnih odnosa nastalih raspadom Čehoslovačke. ${ }^{101}$ Nakon toga, Visoki upravni sud i sam je postavio prethodno pitanje Sudu EU-a o svojoj vezanosti ovakvom odlukom Ustavnog suda, no ubrzo ga je i povuklo. ${ }^{102}$ Do takve je reakcije dovela kombinacija povrijeđenog ponosa, ali i nesuradljivih nacionalnih sudova te nerazumijevanja procesnih pravila prava Europske unije o odnosu nacionalnih sudova i Suda EU-a. ${ }^{103}$ Naime, tijekom postupka češki je Ustavni sud, a kako bi opovrgnuo navode češke Vlade koji nisu podržavali njegovo stajalište, poslao pismo Sudu EU-a u kojem je pojasnio svoje viđenje. Sud EU-a pismo je vratio uz objašnjenje da taj Sud ne razmjenjuje podneske s trećim stranama o postupcima koji se pred njim vode. ${ }^{104} \mathrm{Da}$ je češki

97 Odluka njemačkog Saveznog ustavnog suda 2 BvR 890/16 od 6. rujna 2016. Nakanishi, op. cit. u bilj. 88, str. 20.

98 Lisbon I, op. cit. u bilj. 34, para 102.-108.

99 Capik, A. B.; Petschko, M., One Says the Things Which One Feels the Need to Say, and Which the Other Will Not Understand: Slovak Pension Cases Before the CJEU and Czech Courts, Croatian Yearbook of European Law and Policy, vol. 9, br. 1, str. 61.-76., str. 63. i 64.

100 Presuda Suda Europske unije, Marie Landtová protiv Česká správa socialního zabezpečení, C-399/09, ECLI:EU:C:2011:415 od 22. lipnja 2011., para 41.-49.

101 Capik; Petschko, op. cit. u bilj. 99, str. 63. Pítrová, L., The Judgment of the Czech Constitutional Court in the "Slovak Pensions" Case and its Possible Consequences (In Light of the Fortiter In Re Suaviter In Modo Principle), The Lawyer Quarterly, vol. 3, br. 2, 2013. , str. 86.-101., str. 86. Presuda češkog Ustavnog suda PL ÚS 5/12 od 31. siječnja 2012.(dalje Holubec).

102 Capik; Petschko, op. cit. u bilj. 99, str. 67.

103 Capik; Petschko, op. cit. u bilj. 99, str. 73. Pítrová, op. cit. u bilj. 101, loc. cit.

104 Zbiral, R., Czech Constitutional Court, Judgment of 31 January 2012, Pl. Ús 5/12: A Legal Revolution or Negligible Episode? Court of Justice Decision Proclaimed Ultra Vires, Common Market Law Review, vol. 49, 2012., str. 1.-18., str. 9. Pítrová, op. cit. u bilj. 101, str. 89. Capik; Petschko, op. cit. u bilj. 99, str. 72. 
Ustavni sud odlučio postaviti prethodno pitanje Sudu EU-a, ovaj je dijalog možda mogao otići u potpuno drugom smjeru. ${ }^{105}$

Navedeni primjeri dokazuju kako se dijalog između nacionalnih ustavnih sudova i Suda EU-a vodio od samih početaka europskog integracijskog procesa. Nekad je taj dijalog više podsjećao na svađu, kao u slučaju dijaloga Suda EU-a s talijanskim Sudom. Nekad je to zapravo bio otvoreni sukob, kao u opisanom slučaju s češkim Sudom. Konačno, postojali su i dijalozi kod kojih je, zapravo riječ bila o vrlo konstruktivnim razgovorima, kao u slučajevima koji su se ticali Europskog uhidbenog naloga, a koje je Sud EU-a vodio s njemačkim Ustavnim sudom.

Ipak, najkvalitetniji bi trebali biti oni dijalozi koje su ustavni sudovi dugo izbjegavali. Riječ je o postupcima pokrenutim na temelju zahtjeva za prethodnu odluku sukladno današnjem članku 267. UFEU-a.

\section{USTAVNI SUDOVI I PRETHODNA PITANJA}

U predmetu Kempter, Sud EU-a konstatirao je da je prethodni postupak utemeljen na sudskom dijalogu. ${ }^{106}$ Upravo je izravnost komunikacije koja taj postupak karakterizira ono što mu daje posebnu kvalitetu. ${ }^{107} \mathrm{U}$ prethodnom pitanju, sud koji pokreće postupak mora argumentirano obrazložiti svoja stajališta pri čemu posebno može ukazati na važnost određenih aspekata svojih obrazloženja. ${ }^{108}$ Imajući u vidu relevantnu praksu Suda EU-a, ${ }^{109}$ Rodin navodi kako "nema nikakvih naznaka da Europski sud nacionalne ustavne sudove ne bi smatrao sudovima u smislu prava Zajednice."110 Doista, Sud EU-a nikad nije dovodio u pitanje raspolažu li ustavni sudovi ovlašću iz današnjeg članka 267. UFEU-a, ${ }^{111}$ no, s druge strane, ustavni sudovi nisu bili skloni postavljati prethodna pitanja Sudu EU-a. ${ }^{112}$ Iznimka je, uz austrijski, belgijski Ustavni sud, koji je prvi ustavni sud koji se poslužio ovim institutom. ${ }^{113}$ Jedan od ovakvih belgijskih slučajeva već je spomenuti predmet Flemish Government.

\footnotetext{
105 Capik; Petschko, op. cit. u bilj. 99, str. 71.

106 Presuda Suda Europske unije Willy Kempter KG protiv Hauptzollamt Hamburg-Jonas C-2/06, ECLI:EU:C:2008:78 od 12. veljače 2008., para 42. Capik; Petschko, op. cit. u bilj. 99, str. 68.

107 Bonelli, M., CJEU, C-105/14 Ivo Taricco and others, ECLI:EU:C:2015:555; and C-42/17 M.A.S., M.B., ECLI:EU:C:2017:936 Italian Constitutional Court, Order no. 24/2017, Maastricht Journal of European and Comparative Law, vol. 25, br. 3, 2018., str. 357.373., str. 373 .

108 Claes, op. cit. u bilj. 29, str. 1337.

109 Presuda Suda Europske unije Dorsch Consult Ingenieurgesellschaft mbH protiv Bundesbaugesellschaft Berlin mbH, C-54/96, ECLI:EU:C:1997:413 od 17. rujna 1997. i presuda Suda Europske unije, CARTESIO Oktató és Szolgáltató bt, C-210/06, ECLI:EU:C:2008:723 od 16. prosinca 2008.

110 Rodin, op. cit. u bilj. 59, str. 12.

111 Claes, op. cit. u bilj. 29, loc. cit.

112 Claes, op. cit. u bilj. 29, str. 1332. Drinóczi; Mahoy, op. cit. u bilj. 25, str. 206. Cartabia, op. cit. u bilj. 40, str. 193., Cartabia, M., "Taking Dialogue Seriously": The Renewed Need for a Judicial Dialogue at the Time of Constitutional Activism in the European Union, Jean Monnet Working Paper, br. 12/07, str. 1.-43., str. 22. i 24. Horvat Vuković, op. cit. u bilj. 3, loc. cit. Bonelli, op. cit. u bilj. 107, str. 358.

113 Cartabia, op. cit. u bilj. 112, loc. cit. Claes, op. cit. u bilj. 29, str. 1337. i 1338.
} 
No, u novije vrijeme i neki su se drugi nacionalni ustavni sudovi, počeli odlučivati na ovaj korak. Jedan od prvih nacionalnih ustavnih sudova koji je uputio prethodno pitanje Sudu EU-a bio je španjolski Ustavni sud, pokrenuvši tako dijalog već opisan u ovom radu. Tri mjeseca poslije presude Melloni, u predmetu Jeremy F, Sud EU-a donio je odluku o pitanju iz iste materije u povodu prvog prethodnog pitanja francuskog Ustavnog vijeća. ${ }^{114} \mathrm{U}$ konkretnoj situaciji, Francuska je državljanina Ujedinjene Kraljevine predala Ujedinjenoj Kraljevini zbog kažnjivog djela u vezi s otmicom djeteta. Po izručenju, otkrivena su dodatna kaznena djela koje je isti gospodin počinio prije predaje, odnosno prije izručenja, različita od onog zbog kojega je predan, odnosno izručen. Sukladno članku 27. stavcima 2., 3. i 4. i članku 28. Okvirne odluke u ovakvom se slučaju postupak može voditi protiv osobe zbog spomenutih kaznenih djela, među ostalim, ako je pravosudno tijelo izvršenja, koje je predalo traženu osobu, dalo pristanak. Takvu odluku pravosudno tijelo izvršenja mora donijeti u roku od 30 dana od dana primitka zahtjeva. Kad je pravosudno tijelo izvršenja, u konkretnom slučaju, dalo pristanak za vođenje kaznenog postupka zbog tih, drugih kaznenih djela. Jeremy F. osporavao je ovu odluku pred nadležnim sudom. Taj sud obratio se Ustavnom vijeću, a ono je Sudu EU-a postavilo prethodno pitanje o dopuštenosti takvog pravnog lijeka. Pozivajući se na načelo uzajamnog povjerenja, Sud EU-a je odgovorio da pravo Europske unije koje se odnosi na Europski uhidbeni nalog ne sprječava postojanje i podnošenje ovakvog pravnog sredstva, pod uvjetom da nisu prekoračeni rokovi propisani Okvirnom odlukom. ${ }^{115} \mathrm{I}$ u ovom se slučaju pitanje odnosilo na materiju Europskog uhidbenog naloga koja je, po prirodi stvari, povezana s određenim ustavima zajamčenim temeljnim pravima.

Postupajući prema svom obećanju ${ }^{116}$ iz presude Honeywell, ${ }^{117}$ u siječnju 2014., prvi je put Sudu EU-a prethodno pitanje uputio njemački Ustavni sud ${ }^{118}$ smatrajući da je OMT (Outright Monetary Transaction) program Europske središnje banke ultra vires. ${ }^{119}$ Iako je ovo bio prvi slučaj u kojem je njemački Ustavni sud postavio prethodno pitanje Sudu EU-a taj je slučaj i svojevrstan eksces, koji podsjeća na "pokazivanje mišića", ${ }^{120}$ s obzirom na to da predstavlja određeni otklon od inače vrlo konstruktivnog i međusobno uvažavajućeg dijaloga tih dvaju

114 Ustavno vijeće je u odluci br. 2006-540 DC navelo da zbog ustavnog roka od mjesec dana u kojem mora donijeti svoj pravorijek (čl. 61.-3. Ustava) ne može uputiti prethodno pitanje o interpretaciji direktive Sudu EU-a. Vidjeti Kostadinov, op. cit. u bilj. 7, str. 315. Iz ovoga proizlazi da bi to, u suprotnom, možda i učinilo.

115 C-168/13 od 30. svibnja 2013. ECLI:EU:C:2013:358, para 50. i 72.-74. Kustra, op. cit. u bilj. 86, str. 176. i 177.

116 Claes, op. cit. u bilj. 29, str. 1335.

117 U ovom je predmetu njemački Ustavni sud zaključio kako je prije proglašavanja akta Europske unije ultra vires, potrebno dati priliku Sudu EU-a da donese odluku o konkretnom slučaju. Vidjeti Rodin, op. cit. u bilj. 3, str. 37. Zbiral, op. cit. u bilj. 104 , str. 13. U idućem je paragrafu postavio ovoj kontroli dodatne uvjete, konstatirajući da do nje može doći samo ako je očito da je došlo do djelovanja tijela, odnosno institucija Unije izvan okvira dodijeljenih im ovlasti.

Vidjeti odluku njemačkog Saveznog ustavnog suda, 2 BvR 2661/06, para 61. i 62.

Nakanishi, op. cit. u bilj. 88, str. 21. i Zbiral, op. cit. u bilj. 104, str. 12. navode da je ova presude njemačkog Ustavnog suda odgovor na presudu Suda EU-a Mangold, s čime se u kontekstu dijaloga ustavnih sudova i Suda EU-a, kako se analiziraju u ovom radu, ne bismo nužno složili, bez obzira što se njemački Ustavni sud u ovoj presudi poziva na presudu Mangold Suda EU-a.

118 I u predmetu Solange III. para 125., njemački Ustavni sud, pokazao je otvorenost prema ovoj mogućnosti navodeći kako u konkretnom slučaju Sudu EU-a nije potrebno postavljati prethodno pitanje s obzirom na to da je ispravna primjena prava Europske unije toliko očita da ne ostavlja mjesta razumnoj sumnji.

119 Vidjeti Lohse, E. J., The German Constitutional Court and Preliminary References- Still a Match not Made in Heaven? German Law Journal, vol. 16, br. 6., str. 1491.-1508., str. 1505.

120 U sličnom kontekstu vidjeti i Castillo Ortiz, P. J., Playing the Judicial Card': Litigation Strategies During the Process of Ratification of the Lisbon Treaty, European Law Journal, vol. 20, br. 5, 2014., str. 630.-648., str. 642. 
sudova. ${ }^{121}$ Naime, njemački Ustavni sud doslovno je tražio potvrdu svog stajališta da je OMT program ultra vires, odnosno dao je Sudu EU-a uputu kakvu bi odluku trebao donijeti, ${ }^{122} \mathrm{u}$ tonu koji bi se mogao nazvati i agresivnim ili prijetećim. ${ }^{123}$ Štoviše, taj je Sud najavio da će, i ako odluka Suda EU-a podrži OMT program, provesti svoju "kontrolu identiteta" koja se može provesti samo na temelju njemačkog ustavnog prava, no ne i prava Europske unije. ${ }^{124}$

Sud EU-a je u predmetu Gauweiler ipak podržao osporavani program, odbijajući argument talijanske vlade "da predmetni zahtjev za prethodnu odluku Sud ne može ispitivati s obzirom na to da sud koji ga je uputio ne priznaje konačnu i obvezujuću interpretativnu vrijednost odgovora koji mu povodom tog zahtjeva daje Sud” te naglašavajući “da presuda Suda donesena u prethodnom postupku obvezuje nacionalni sud u pogledu tumačenja ili ocjene valjanosti akata institucija Unije o kojima je riječ, kada potonji odlučuje u glavnom postupku." ${ }^{125}$ Ovako je Sud EU-a podsjetio da bi nepriznavanje učinka mjere Europske unije na području Njemačke, čiju je valjanost potvrdio Sud EU-a bilo ozbiljno kršenje prava Europske unije. ${ }^{126}$

Njemački Ustavni sud shvatio je poruku te u svojoj presudi potvrdio da OMT program nije u suprotnosti s njemačkim Ustavom, ali i zadržao pravo daljnjeg nadzora njegove implementacije. ${ }^{127}$ Tako je njemački Ustavni sud, u posljednji trenutak, izabrao izbjeći otvoreni sukob sa Sudom EU-a te nakon češkog postati drugi ustavni sud koji bi mjeru Europske unije proglasio ultra vires. Za razliku od spomenutog češkog slučaja, ovaj se dijalog vodio u povodu prethodnog pitanja. Sigurno je da je izravna komunikacija između sudova pridonijela izbjegavanju otvorenog sukoba koji je, barem na početku ovog dijaloga, postojao kao realna prijetnja.

Talijanski Ustavni sud vrlo je rano za sebe ustvrdio kako nije ovlašten uputiti Sudu EU-a prethodno pitanje u odluci 536/1995., no zbog procesnih promjena unutar vlastitog ustavnosudskog sustava, u odluci 103/2008., promijenio je taj stav i postavio Sudu EU-a prvo prethodno pitanje. ${ }^{128}$ Međutim, kao ilustrativan primjer kvalitetnog međusudskog dijaloga kroz postupak pokrenut prethodnim pitanjem najkorisnije je uzeti tzv. Taricco slučajeve, u okviru kojih je talijanski Ustavni sud to učinio po treći put. ${ }^{129}$ Dijalog je započeo kada je Sud EU-a, u svibnju 2015. donio presudu Taricco I. u kojoj je rekao da nacionalni sud ne smije primijeniti

121 Fabbrini, F., After the OMT Case: The Supremacy of EU Law as the Guarantee of the Equality of the Member States, German Law Review, vol. 16, br. 4, 2015., str. 1003.-1023., str. 1004.

122 Pernice, I., A Difficult Partnership between Courts: The First Preliminary Reference by the German Federal Constitutional Court to the CJEU, Maastricht Journal of European and comparative law, vol. 23, br. 1, 2014., str. 3.-13., str. 9., Odluka OMT, para 55.

123 Claes, op. cit. u bilj. 29, str. 1341. Fabbrini, op. cit. u bilj. 121, str. 1012.

124 Odluka OMT, para 103., Drinóczi; Mahoy, op. cit. u bilj. 25, str. 199.

125 Presuda Suda Europske unije Peter Gauweiler i dr. protiv Deutscher Bundestaga, C-62/14, ECLI:EU:C:2015:400 od 16. lipnja 2015., para 13. i 16.

126 Fabbrini, op. cit. u bilj. 121, str. 1005. i 1014. Vidjeti presudu Suda Europske unije, Brasserie du Pêcheur SA protiv Bundesrepublik Deutschland and The Queen $v$ Secretary of State for Transport, ex parte: Factortame Ltd and others, C-46/93 i C-48/93, ECLI:EU:C:1996:79 od 5. ožujka 1996. para 57. Vidjeti i Rodin, op. cit. u bilj. 59, str. 21.

127 Presuda njemačkog Ustavnog suda 2 BvR 2728/13, 2 BvR 2729/13, 2 BvR 2730/13, 2 BvR 2731/13 i 2 BvE 13/13 od 21. lipnja 2016. (u daljnjem tekstu: Presuda OMT), para 208., 210., 218. i 220. Payandah, str. 400., Drinóczi; Mahoy, op. cit. u bilj. 25, loc. cit.

128 Kustra, op. cit. u bilj. 86, str. 165. Bonelli, op. cit. u bilj. 107., str. 358. Pitanje se odnosilo na usklađenost poreznog zakonodavstva s pravilima Europske unije o slobodi pružanja usluga i državnim potporama.

129 Paris, Carrot and Stick. The Italian Constitutional Court's Preliminary Reference in the Case Taricco, Questions of International Law, 31.3.2017. dostupno na http://www.qil-qdi.org/carrot-stick-italian-constitutional-courts-preliminary-reference-case-taricco/\#ftn1. Pristupljeno 9. veljače 2020. Odluka talijanskog Ustavnog suda N. 24. od 23. studenoga 2016. (dalje Odluka Taricco). 
nacionalni propis koji se odnosi na zastaru ako "taj nacionalni propis sprječava izricanje učinkovitih i odvraćajućih sankcija u značajnom broju slučajeva teških prijevara koje štete financijskim interesima Unije ili propisuje mnogo duže rokove zastare za slučajeve prijevara koje štete financijskim interesima dotične države članice, nego za one koje štete financijskim interesima Unije". ${ }^{130}$ Talijanski Ustavni sud je u svojoj odluci 24/2017., u tonu vrlo sličnom onom njemačkog Ustavnog suda u predmetu OMT, uputio pitanje Sudu EU-a, pojašnjavajući zašto je presuda Taricco I. sporna s aspekta talijanskog ustavnog prava. Zatražio je potvrdu svojeg viđenja te presude i relevantnih odredbi UFEU-a te konstatirao da kad bi se Sud EU-a složio s ovim njegovim tumačenjem, ne bi bilo potrebe za dovođenjem u pitanje njezine ustavnosti u talijanskom pravnom poretku. ${ }^{131}$ Zanimljivo, talijanski se Sud, pritom, pozivao na svoj "ustavni identitet", dotad malo poznat talijanskoj ustavnopravnoj praksi, ${ }^{132}$ članak 4. stavak 2. UEU-a, kao i na načelo zakonitosti kako je formulirano člankom 7. Europske konvencije za zaštitu ljudskih prava i temeljnih sloboda, člankom 49. Povelje EU-a o temeljnim pravima i člankom 25. talijanskog Ustava. ${ }^{133}$ Talijanski Sud, međutim, nije objasnio zašto ove ustavne odredbe ulaze u samu srž Ustava na način da bi ih se trebalo smatrati ustavnim identitetom Italije. ${ }^{134} \mathrm{U}$ presudi Taricco II. ${ }^{135}$ Sud EU-a se ovim argumentom Ustavnog suda nije bavio. Ipak, navodeći kako "načelo zakonitosti kaznenih djela i kazni čini dio ustavnih tradicija zajedničkih državama članicama", dakle ne ulazeći u dijalog oko talijanskog ustavnog identiteta, dopunio je odluku u Taricco I. ${ }^{136}$ Pravilo o neprimjeni nacionalnog zakonodavstva koje onemogućuje izricanje učinkovitih i odvraćajućih kaznenih sankcija u značajnom broju slučajeva teških prijevara kojima se nanosi šteta financijskim interesima Europske unije vrijedi i dalje osim ako takvom neprimjenom dolazi do povrede načela zakonitosti kaznenih djela i kazni, "zbog nepreciznosti primjenjivog zakona ili retroaktivne primjene zakonodavstva kojim se propisuju stroži uvjeti kaznenog progona od onih koji su bili na snazi u trenutku počinjenja kaznenog djela". ${ }^{137}$

Ovakvom reformulacijom ranije presude, Sud EU-a izbjegao je mogući sukob s talijanskim Ustavnim sudom te potvrdio teoriju da su postupci pokrenuti prethodim pitanjem od strane ustavnih sudova najbolji način za njihovo učinkovito sudjelovanje u dijalogu sa Sudom EU-a. ${ }^{138}$ Predmet Jeremy F. potvrdio je tezu o njihovoj ekonomičnosti. Konkretni je postupak trajao manje od dva mjeseca. ${ }^{139}$

\footnotetext{
130 Presuda Suda Europske unije, Kazneni postupak protiv Ive Taricca i dr., C-105/14, ECLI:EU:C:2015:555, od 8. rujna 2015., para 58.

131 Odluka Taricco, para 7. Paris, op. cit. u bilj. 129.

132 Bonelli, op. cit. u bilj. 107, str. 362.

133 Vidjeti para 4.i 6. Odluke Taricco.

134 Paris, op. cit. u bilj. 129.

135 Presuda Suda Europske unije, M. A. S. i M. B. protiv Presidente del Consiglio dei Ministri, C-42/17, ECLI:EU:C:2017:936 od 5 prosinca 2017. (dalje u tekstu Taricco II.).

136 Taricco II., para 53.

137 Taricco II., para 62.

138 Bonelli, op. cit. u bilj. 107, str. 373.

139 Zahtjev za prethodnu odluku podnesen je prema članku 23.a Statuta Suda EU-a koji regulira hitni postupak.
} 


\section{ZAKLJUČAK}

U zaštiti ustavnih identiteta i postavljanju ustavnih granica, ${ }^{140}$ ustavni sudovi država članica bili su, na neki način, prisiljeni ulaziti u dijaloge sa Sudom EU-a i to od početka europskih integracija pa do danas, ${ }^{141}$ a pogotovo nakon stupanja na snagu Lisabonskog ugovora i njegova članka 4. stavka 2. Ustavni su sudovi dugo izbjegavali mogućnost postavljanja prethodnog pitanja Sudu EU-a. ${ }^{142}$ Zadovoljavali su se, kako kaže Claes, skrivenim ili tihim dijalozima, ${ }^{143}$ odgovarajući na međusobnu praksu, koji put na više, koji put na manje uspješan način.

Primjeri za svaki od tih načina analizirani su u ovom radu. U tom smislu, smatramo da je moguće izdvojiti tri osnovne vrste ovakvih dijaloga:

a) poduke koje je svojom praksom Sud EU-a odgovarao na praksu nacionalnih sudova: primjer za ovo je najranija praksa Suda EU-a, presude Costa v. E. N. E. L. i Simmenthal koja je zapravo bila reakcija na praksu talijanskog Ustavnog suda, kao i presude Melki i Abdeli te A protiv B u kojima je Sud EU-a odgovarao na ustavne reforme Francuske, odnosno Austrije;

b) kvalitetni dijalozi koje je Sud EU-a vodio, u prvom redu, s njemačkim Ustavnim sudom, kao primjerice u presudi Aranyosi i Căldăraru koja je bila odgovor na praksu tog Suda, ali i poticaj na njezin daljnji razvoj u smislu otvorenog odnosa prema pravu Europske unije i

c) otvoreni sukobi, za što je zapravo, zasad, jedini slučaj, s češkim Ustavnim sudom.

Samo je po sebi jasno da je izravno obraćanje koje omogućava ${ }^{144}$ postavljanje prethodnog pitanja Sudu EU-a od strane bilo kojeg nacionalnog suda, pa tako i ustavnog, najjasniji, najbrži i najekonomičniji način komunikacije, ${ }^{145}$ a svakako i najsigurniji. Naime, kod neizravnih dijaloga praksom ustavnih sudova, odnosno Suda EU-a, do komunikacije može, ali i ne mora doći, a koliko će ona biti izravna i nedvosmislena, opet ovisi o njezinim sudionicima. Sve navedene prednosti dijaloga s pomoću instituta prethodnog pitanja, vrijede unatoč nekim njegovim nedostacima. Osim nacionalnih procesnih prepreka, na koje ukazuje i talijanska praksa, ali i primjerice članak 37. Ustavnog zakona o Ustavnom sudu $\mathrm{RH},{ }^{146}$ kao problem navodi se i činjenica da po postavljanju pitanja, ustavni sudovi, praktički, nestaju iz postupka. ${ }^{147} \mathrm{~S}$ druge strane, na ovaj se argument može odgovoriti protuargumentom da svaki nacionalni sud, ako smatra da treba tražiti pojašnjenje od Suda EU-a, može ponovno postaviti pitanje pa tako i ustavni sud, jednako kao i postupiti prema članku 43. Statuta Suda EU-a koji kaže da ako je smisao ili

140 Horvat Vuković, op. cit. u bilj. 48, str. 491.

U svojoj Odluci K-18/04 od 11. svibnja 2005., poljski Ustavni sud navodi da su u slučaju sukoba ustavnih normi i normi Unije moguća tri scenarija: promjena Ustava, promjena odredbi prava Europske unije ili povlačenje iz Unije Drinoczi, op. cit. u bilj. 38, str. 147. Vidjeti i Preshova, op. cit. u bilj. 26, str. 297.

op cit. u bilj. 59, str. 14 . Claes, op. cit. u bilj. 29, str 1332. Drinóczi; Mahoy, op. cit. u bili. 25, str. 206. Cartabia, op. cit. un bilj. 40, loc. cit. Cartabia op. cit. u bilj. 112, loc. cit. Horvat Vuković, op. cit. u bilj. 3, loc. cit. Bonelli, op. cit. u bilj. 107, str. 358.

143 Claes, op. cit. u bilj. 29, str .1337.

144 Odnosno, na koje obvezuje članak 267. kad je riječ o sudu posljednje instance, što katkad može biti i ustavni sud.

145 Claes, op. cit. u bilj. 29, loc. cit. Rodin, op. cit. u bilj. 59, str. 12.

146 Ustavni zakon o Ustavnom sudu RH (Narodne novine, broj 99/1999, 29/2002, 49/2002).

147 von Bogdandy; Schill, op. cit. u bilj. 1, str. 1449. 
doseg presude nejasan, Sud EU-a daje njezino tumačenje na prijedlog bilo koje stranke ili institucije Unije koja za to dokaže svoj pravni interes. Konačno, kada govorimo o nedostacima tu je i neshvaćanje načela lojalne suradnje iz članka 4. stavka 3. UFEU-a, dovoljno ozbiljno kako od strane ustavnih sudova, ${ }^{148}$ tako i od strane Suda EU-a. ${ }^{149}$ Ustavni sudovi trebali bi konačno prihvatiti članak 267. kao temelj dijaloga sa Sudom EU-a, kao i konačni i obvezujući učinak njegovih presuda, dok bi Sud EU-a trebao, u svim postupcima u vezi s člankom 4. stavkom 2. UEU-a konzultirati i uvažavati i nacionalne ustavne sudove i njihovo zakonodavstvo. ${ }^{150} \mathrm{Na}$ ovaj način, stvorili bi se uvjeti za odvijanje konstruktivnih i kvalitetnih dijaloga između ovih sudova, kao saveznika, ${ }^{151} \mathrm{u}$ duhu međusobnog uvažavanja i suradnje, ${ }^{152} \mathrm{u}$ stanju neriješene hijerarhije među temeljnim normama, ${ }^{153}$ tipične i prihvatljive u heterarhičnom sustavu kao što je Europska unija. ${ }^{154}$

\section{LITERATURA}

\section{KNJIGE I ČLANCI}

1. Besselink, L. F. M., National and constitutional identity before and after Lisbon, Utrecht Law Review, vol. 6, br. 3, 2010., str. 36. -49 .

2. Blagojević, A., Procedures Regarding National Identity Clause in the National Constitutional Court's and the CJEU's Case-law u: Duić, D.; Petrašević, T. (ur.), Procedural Aspects of EU Law, Jean Monnet International Scientific Conference, 2017., str. 210.-237.

3. Bonelli, M., CJEU, C-105/14 Ivo Taricco and others, ECLI:EU:C:2015:555; and C-42/17 M.A.S., M.B., ECLI:EU:C:2017:936 Italian Constitutional Court, Order no. 24/2017, Maastricht Journal of European and Comparative Law, vol. 25, br. 3, 2018., str. 357.-373.

4. Bui, S. N., Globalization of Constitutional Identity, Washington International Law Journal, vol. 26, br. 3, 2017., str. 463.-533.

5. Capik, A. B.; Petschko, M., One Says the Things Which One Feels the Need to Say, and Which the Other Will Not Understand: Slovak Pension Cases Before the CJEU and Czech Courts, Croatian Yearbook of European Law and Policy, vol. 9, br.1, str. 61.-76

6. Cartabia, M., The Italian Constitutional Court and the Relationship Between the Italian Legal System and the European Community, Michigan Journal of International Law, vol. 12, br. 1, 1990., str. 173.-203.

7. Cartabia, M., "Taking Dialogue Seriously": The Renewed Need for a Judicial Dialogue at the Time of Constitutional Activism in the European Union, Jean Monnet Working Paper, br. 12/07.

8. Castillo Ortiz, P.J., Playing the Judicial Card': Litigation Strategies During the Process of Ratification of the Lisbon Treaty, European Law Journal, vol. 20, br. 5, 2014., str. 630.-648.

\footnotetext{
148 von Bogdandy; Schill, op. cit. u bilj. 1, loc. cit. Vidjeti i češki slučaj Holubec.

149 Claes, op. cit. u bilj. 29, str. 1341. Bonelli, op. cit. u bilj. 107, str. 366. Vidjeti i češki slučaj Holubec.

150 Drinóczi; Mahoy, op. cit. u bilj. 25, str. 198.

151 Claes, op. cit. u bilj. 29, str. 1334.

152 Horvat Vuković, op. cit. u bilj. 3, str. 270.

153 Ćapeta, op. cit. u bilj. 55, str. 77.

154 von Bogdandy; Schill, op. cit. u bilj. 1, loc. cit.
} 
9. Claes, M., Luxembourg, Here We Come, German Law Journal, vol. 16, br. 6, str. 1331.-1342.

10. Cloots, E., National identity in EU Law, Oxford University Press, 2015.

11. Cloots, E., National Identity, Constitutional Identity, and Sovereignty in the EU, Netherlands Journal of Legal Philosophy, vol. 45, br. 2, 2016., str. 82.-98.

12. Ćapeta, T., Nacionalni Ustav i nadređenost prava EU u eri pravnog pluralizma, Zbornik Pravnog fakulteta u Zagrebu, vol. 59, br. 1, 2009., str. 63.-96.

13. Drinóczi, T., Hungarian Constitutional Court: The Limits of EU Law in the Hungarian Legal System, Vienna Journal on International Constitutional Law, vol. 11, br. 1, 2017., str. 139.-151.

14. Drinoczi, T.; Mahoy, A., The Preliminary Ruling Procedure and the Identity Review u: Duić, D.; Petrašević, T. (ur.), Procedural Aspects of EU Law, Jean Monnet International Scientific Conference, 2017., str. 192.-209., str. 198.

15. Fabbrini, F., After the OMT Case: The Supremacy of EU Law as the Guarantee of the Equality of the Member States, German Law Review, vol. 16, br. 4, 2015., str. 1003.-1023.

16. Horvat Vuković, A., Ustavni sud Republike Hrvatske kao "europski" sud i očuvanje nacionalnih standarda zaštite temeljnih ljudskih prava i sloboda, Zbornik Pravnog fakulteta u Zagrebu, vol. 69, br. 2, 2019., str. 249.-276.

17. Horvat Vuković, A., "U ime ustava" - materijalne granice promjene ustava, Zbornik Pravnog fakulteta u Zagrebu, vol. 65, br. 3-4, 2015., str. 481.-503.

18. Jacobsohn, G., Constitutional identity, The Review of Politics, vol. 68, br. 3, 2006., str. 361.-397.

19. Jardim de Santa Cruz Oliveira, M. A., International Trade Agreements Before Domestic Courts, Springer International Publishing, 2015.

20. Kostadinov, B., Ustavni identitet, u: Bačić, J. (ur.), Dvadeseta obljetnica Ustava Republike Hrvatske, Hrvatska akademija znanosti i umjetnosti - Znanstveno vijeće za državnu upravu, pravosuđe i vladavinu prava, 2011., str. 305-337.

21. Kustra, A., The First Preliminary Questions to the Court of Justice of the European Union Referred by Italian Corte Costituzionale, SpanishTribunal Constitucional and French Conseil Constitutionnel Comparative Law Review, vol. 16, 2013.,str. 159.-182., str. 169.

22. Lohse, E. J., The German Constitutional Court and Preliminary References - Still a Match not Made in Heaven? German Law Journal, vol. 16, br. 6, str. 1491.-1508.

23. Nakanishi, Y., Completion of EU Measures Through Court Decisions: The Example of the European Arrest Warrant, Hitotsubashi journal of law and politics, vol. 45, 2017., str. 13-21.

24. Omejec, J., Veliki njemački ustav i nepromjenjiva ustavna načela u praksi Saveznog ustavnog suda, Zbornik "Pravo i pravda 2015" Pravnog fakulteta Univerziteta u Beogradu, 2016., dostupno na https://www.bib.irb.hr/792156. Pristupljeno 10. veljače 2020.

25. Pernice, I., A Difficult Partnership between Courts: The First Preliminary Reference by the German Federal Constitutional Court to the CJEU, Maastricht Journal of European and comparative law, vol. 23, br. 1, 2014., str. 3.-13.

26. Pítrová, L., The Judgment of the Czech Constitutional Court in the "Slovak Pensions" Case and its Possible Consequences (In Light of the Fortiter In Re Suaviter In Modo Principle), The Lawyer Quarterly, vol. 3, br. 2, 2013., str. 86.-101.

27. Preshova, D., Battleground or meeting point? Respect for national identities in the European union - Article 4(2) of the treaty on European union, Croatian Yearbook of European Law and Policy, vol. 8, br.1, 2012., str. 267.-298.

28. Rodin, S., National Identity and Market Freedoms After the Treaty of Lisbon, Croatian Yearbook of European Law and Policy, vol. 7, br.1, 2011., str. 11.-41. 
29. Rodin, S., Odnos Ustavnog suda RH i Suda pravde Europskih zajednica u Luxembourgu nakon ulaska Republike Hrvatske u punopravno članstvo u Europskoj uniji, u: Barbić, J. (ur.), Hrvatsko ustavno sudovanje, Hrvatska akademija znanosti i umjetnosti, 2009., str. 247-277.

30. Rodin, S., Pravo Europske unije i pravni poredak Republike Hrvatske nakon 20 godina hrvatskog ustava, Zbornik HAZU Zagreb, Hrvatska, 2010., str. 1.-31.

31. von Bogdandy, A.; Schill, S., Overcoming absolute primacy: Respect for national identity under the Lisbon Treaty, Common Market Law Review, vol. 48, br. 5, 2011., str. 1417.-1453.

32. Zbiral, R., Czech Constitutional Court, Judgment of 31 January 2012, Pl. Ús 5/12: A Legal Revolution or Negligible Episode? Court of Justice Decision Proclaimed Ultra Vires, Common Market Law Review, vol. 49, 2012., str. 1.-18.

\section{SUDSKA PRAKSA}

1. Presuda njemačkog Saveznog ustavnog suda, 2 BvE 2/08, 2 BvE5/08, 2 BvR 1010/08., 2 BvR 1022/08, 2 BvR 1259/08, 2 BvR 182/09 od 30. lipnja 2009. dostupna na https://www.bundesverfassungsgericht.de/SharedDocs/Entscheidungen/EN/2009/06/es20090630-2bve000208en.html. Pristupljeno 10. veljače 2020.

2. Presuda Suda Europske unije Ilonka Sayn-Wittgenstein protiv Landeshauptmann von Wien, C-208/09, ECLI:EU:C:2010:806 od 22. prosinca 2010.

3. Presuda Suda Europske unije Malgožata Runevič-Vardyn i Łukasz Paweł Wardyn protiv Vilniaus miesto savivaldybes administracija i dr., C-391/09, ECLI:EU:C:2011:291 od 12. svibnja 2011.

4. Presuda Suda Europske unije Nabiel Peter Bogendorff von Wolffersdorff protiv Standesamt der Stadt Karlsruhe i Zentraler Juristischer Dienst der Stadt Karlsruhe, C-438/14, ECLI:EU:C:2016:401 od 2. lipnja 2014.

5. Presuda Suda Europske unije Michaniki AE protiv Ethniko Symvoulio Radiotileorasis i Ypourgos Epikrateias, C-213/07, ECLI:EU:C:2008:731 od 16. prosinca 2008.

6. Presuda Suda Europske unije Vlada Communauté française i Gouvernement wallon protiv Gouvernement flamand, C-212/06, ECLI:EU:C:2008:178 od 1. travnja 2008.

7. Presuda Suda Europske unije Omega Spielhallen- und Automatenaufstellungs-GmbH protiv Oberbürgermeisterin der Bundesstadt Bonn, C-36/02, ECLI:EU:C:2004:614 od 14. listopada 2004.

8. Mišljenje nezavisnog odvjetnika Madura u predmetu Cristiano Marrosu i Gianluca Sardino protiv Aziedna Ospidaliera Ospedale, C-53/04, ECLI:EU:C:2005:569 od 20. rujna 2005.

9. Odluka njemačkog Saveznog ustavnog suda 2 BvR 2728/13, 2729/13, 2730/13, 2731/13 i 13/13 od 14. siječnja 2014.

10. Presuda njemačkog Saveznog ustavnog suda BVerfGE 37, 271 (2 BvL 52/71) od 29. svibnja 1974.

11. Presuda njemačkog Saveznog ustavnog suda BVerfGE 73, 339 (2 BvR 197/83) od 22. listopada 1986.

12. Odluka njemačkog Saveznog ustavnog suda BVerfGE 89, 155 od 14. siječnja 2014.

13. Presuda češkog Ustavnog suda PL US 19/08 od 26. studenoga 2008.

14. Presuda češkog Ustavnog suda PL US 29/09 od 3. studenoga 2009.

15. Presuda poljskog Ustavnog suda K-32/09 od 24. listopada 2010.

16. Presude poljskog Ustavnog suda K-45/09 od 16. studenoga 201

17. Presuda Suda Europske unije Ministerio Fiscal Ante el Tribunal Constitucional protiv Stefano Melloni, C-399/11, ECLI:EU:C:2013:107, od 26. veljače 2013. 
18. Odluka mađarskog Ustavnog suda 22/2016 (XII 5) od 30. studenoga 2016.

19. Presuda talijanskog Ustavnog suda N. 183 od 27. prosinca 1973.

20. Presuda talijanskog Ustavnog suda N. 170 od 8. lipnja 1984.

21. Odluka talijanskog Ustavnog suda N. 1146 od 15. do 29. prosinca 1988.

22. Presuda španjolskog Ustavnog suda 1/2004 od 13.prosinca 2004.

23. Odluka francuskog Ustavnog vijeća 2006-540 DC od 27. srpnja 2006.

24. Odluka USRH U-I-3597/2010, U-I-3847/2010, U-I-692/2011, U-I-898/2011 i U-I-994/2011 od 29. srpnja 2011.

25. Priopćenje USRH Broj: SuS-1/2013 od 14. studenoga 2013.

26. Upozorenje USRH U-VIIR-5292/2013 od 28. listopada 2013.

27. Odluka USRH U-VIIR-1159/2015 od 8. travnja 2015.

28. Odluka USRH U-VIIR-4640/2014 od 12. kolovoza 2014.

29. Odluka USRH U-VIIR-1158/2015 od 21.travnja 2015.

30. Odluka USRH od U-II-6111/2013 od 10. listopada 2017.

31. Presuda talijanskog Ustavnog suda, N. 14. od 7. ožujka 1964.

32. Presuda Suda Europske unije Flaminio Costa protiv E. N. E. L., C-6/64, ECLI:EU:C:1964:66 od 15. srpnja 1964.

33. Presuda Suda Europske unije Amministrazione delle Finanze dello Stato protiv Simmenthal SpA C-106/77, ECLI:EU:C:1978:49 od 9. ožujka 1978.

34. Presuda Suda Europske unije Aziz Melki i Sélim Abdeli, C-188/10 i C-189/10, ECLI:EU:C:2010:363 od 22. lipnja 2010.

35. Presuda Suda Europske unije A protiv B, C-112/13., ECLI:EU:C:2014:2195 od 11. rujna 2014.

36. Presuda Suda Europske unije Internationale Handelsgesellschaft mbH protiv Einfuhr- und Vorratsstelle für Getreide und Futtermittel, C-11/70, ECLI:EU:C:1970:114 od 17. prosinca 1970.

37. Presuda Suda Europske unije J. Nold, Kohlen- und Baustoffgroßhandlung protiv Ruhrkohle Aktiengesellschaft, C-4/73,. ECLI:EU:C:1974:51 od 14. svibnja 1974.

38. Odluka talijanskog Ustavnog suda N. 232. od 21. travnja 1989.

39. Odluka njemačkog Saveznog ustavnog suda 2 BvL 1/97 od 7. lipnja 2000.

40. Odluka njemačkog Saveznog ustavnog suda 2 BvR 2735/14 od 15. veljače 2015.

41. Presuda Suda Europske unije, Pál Aranyosi i Robert Căldăraru, C-404/15 i 659/15 PPU, ECLI:EU:C:2016:198 od 5. travnja 2016.

42. Odluka njemačkog Saveznog ustavnog suda 2 BvR 890/16 od 6. rujna 2016.

43. Presuda Suda Europske unije, Marie Landtová protiv Česká správa socialního zabezpečení, C-399/09, ECLI:EU:C:2011:415 od 22. lipnja 2011.

44. Presuda češkog Ustavnog suda PL ÚS 5/12 od 31. siječnja 2012.

45. Presuda Suda Europske unije Willy Kempter KG protiv Hauptzollamt Hamburg-Jonas C-2/06, ECLI:EU:C:2008:78 od 12. veljače 2008.

46. Presuda Suda Europske unije Dorsch Consult Ingenieurgesellschaft mbH protiv Bundesbaugesellschaft Berlin mbH, C-54/96, ECLI:EU:C:1997:413 od 17. rujna 1997.

47. presuda Suda Europske unije, CARTESIO Oktató és Szolgáltató bt, C-210/06, ECLI:EU:C:2008:723 od 16. prosinca 2008.

48. Odluka njemačkog Saveznog ustavnog suda, 2 BvR 2661/06. 
49. Presuda Suda Europske unije, Brasserie du Pêcheur SA protiv Bundesrepublik Deutschland and The Queen $v$ Secretary of State for Transport, ex parte: Factortame Ltd and others, C-46/93 i C-48/93, ECLI:EU:C:1996:79 od 5. ožujka 1996.

50. Presuda Suda Europske unije Peter Gauweiler $i$ dr. protiv Deutscher Bundestag, C-62/14, ECLI:EU:C:2015:400 od 16. lipnja 2015.

51. Presuda njemačkog Saveznog ustavnog suda 2 BvR 2728/13, 2 BvR 2729/13, 2 BvR 2730/13, 2 BvR 2731/13 i 2 BvE 13/13 od 21. lipnja 2016.

52. Odluka talijanskog Ustavnog suda N. 24. od 23. studenoga 2016.

53. Presuda Suda Europske unije, Kazneni postupak protiv Ive Tariccai dr., C-105/14, ECLI:EU:C:2015:555, od 8. rujna 2015.

54. Presuda Suda Europske unije, M.A.S. i M.B. protiv Presidente del Consiglio dei Ministri, C-42/17, ECLI:EU:C:2017:936 od 5. prosinca 2017.

55. Presuda poljskog Ustavnog suda K-18/04 od 11. svibnja 2005.

\section{PROPISI}

1. Pročišćene verzije Ugovora o Europskoj uniji i Ugovora o funkcioniranju Europske unije dostupne su na https://eur-lex.europa.eu/legal-content/HR/TXT/?uri=CELEX \%3A 12016ME\%2FTXT. Pristupljeno 10. veljače 2020.

2. Povelja Europske unije o temeljnim pravima, dostupno na https://eurlex.europa.eu/ legal-content/ HR/TXT/PDF/?uri=CELEX:12016P/TXT\&from=FR. Pristupljeno 10. veljače 2020.

\section{MREŽNI IZVORI (BLOGOVI)}

1. Franssen, V. Melloni as a Wake-up Call - Setting Limits to Higher National Standards of Fundamental Rights' Protection, European Law Blog, News and Comments on EU Law, 10. ožujka 2014., dostupno na https://europeanlawblog.eu/2014/03/10/melloni-as-a-wake-up-call-setting-limits-to-highernational-standards-of-fundamental-rights-protection/. Pristupljeno 9. veljače 2020.)

2. Nowag, J., A new Solange judgment from Germany - or nothing to worry about? Völkerrechtsblog, 22. ožujka 2016. DOI: 10.17176/20171201-110929 dostupno na https://voelkerrechtsblog.org/a-newsolange-judgment-from-germany-or-nothing-to-worry-about/. Pristupljeno 9. veljače 2020.

3. Paris, Carrot and Stick. The Italian Constitutional Court's Preliminary Reference in the Case Taricco, Questions of International Law, 31. ožujka 2017. dostupno na http://www.qil-qdi.org/carrot-stick-italian-constitutional-courts-preliminary-reference-case-taricco/\#-ftn1. Pristupljeno 9. veljače 2020. 


\section{DIALOGUES BETWEEN CONSTITUTIONAL COURTS OF THE EU MEMBER STATES AND THE COURT OF JUSTICE OF THE EU}

\section{Summary}

In the context of the discourse on constitutional identities, national constitutional courts enter into various forms of dialogue with the Court of Justice of the EU. After having engaged for an extended period of time in exclusively indirect dialogues that were more or less successful and were realised through their own practices, national constitutional courts started making use of the possibility offered to them pursuant to Article 267 of the Treaty on the Functioning of the European Union, i.e., the preliminary ruling procedure. The paper aims to prove that the dialogues which constitutional courts engage in with the Court of Justice of the EU are the most successful forms of their communication. For that purpose the paper compares these dialogues with indirect forms of communication between constitutional courts and the Court of Justice of the EU. It is in this context that the paper, following introductory considerations in the second part, considers the concept of constitutional identity from the viewpoint of the Court of Justice of the EU and the viewpoint of national constitutional courts. The third part of the paper analyses different forms of indirect dialogue between constitutional courts and the Court of Justice of the EU and draws conclusions about their effectiveness. The fourth part analyses particular procedures instituted before the Court of Justice of the EU by constitutional courts and points out the pros and cons of these procedures. Finally, the paper concludes that the procedures instituted by national constitutional courts pursuant to Article 267 of the Treaty on the Functioning of the European Union are the most direct and the most efficient forms of their communication with this Court.

Keywords: national constitutional courts, the Court of Justice of the European Union, dialogue, constitutional identity, preliminary ruling procedure, Article 267 of the Treaty on the Functioning of the European Union (TFEU)

\section{(c) (1) (8)}

This work is licensed under a Creative Commons

Attribution-NonCommercial 4.0 International License.

Stjepan Novak, PhD, Ministry of Internal Affairs, Republic of Croatia, Ulica grada Vukovara 33, 10000 Zagreb. E-mail address: stjepannovak@hotmail.com. ORCID: https://orcid.org/0000-0002-6600-4974. 